\title{
Limnological description of the Lakes Zürich, Lucerne, and Cadagno
}

\author{
Peter Bossard ${ }^{1, *}$, Sonja Gammeter ${ }^{5}$, Christine Lehmann ${ }^{3}$, \\ Ferdinand Schanz ${ }^{4}$, Reinhard Bachofen ${ }^{3}$, Hans-Rudolf Bürgi ${ }^{2}$, Daniel Steiner ${ }^{1}$ and \\ Ulrich Zimmermann ${ }^{5}$ \\ ${ }^{1}$ Limnological Research Center, EAWAG, CH-6047 Kastanienbaum, Switzerland \\ ${ }^{2}$ EAWAG/ETH, Ueberlandstr. 133, CH-8600 Dübendorf, Switzerland \\ ${ }^{3}$ Institute of Plant Biology, University of Zürich, Zollikerstr. 107, CH-8008 Zürich, Switzerland \\ ${ }^{4}$ Limnological Station, University of Zürich, Seestrasse 187, CH-8802 Kilchberg, Switzerland \\ ${ }^{5}$ Wasserversorgung Zürich, Hardhof 9, CH-8023 Zürich, Switzerland
}

Key words: Lake Zürich, Lake Lucerne, Lake Cadagno, limnology, primary production, phytoplankton, nutrients.

\begin{abstract}
This introductory article of the special GAP issue gives an overview on general limnological characteristics of the prealpine Lakes Zürich and Lucerne and the alpine Lake Cadagno and reports on the specific situation of primary production parameters during the international GAP Workshop in mid September 1999. Furthermore, it describes methods used for water analysis and fieldwork in these lakes.

A comparison of data related to primary production in the three lakes in September 1999 during stratification shows that (i) phytoplankton community structure varied considerably between the lakes. The dominating algae were Planktothrix rubescens in Lake Zürich, various chrysophytes and diatoms in Lake Lucerne, and Echinocoleum elegans in Lake Cadagno, (ii) the euphotic zone in Lake Lucerne was considerably deeper (app. $15 \mathrm{~m}$ ) than in the other two lakes (app. $10 \mathrm{~m}$ ), (iii) chlorophyll $a$ standing crop was highest in mesotrophic Lake Zürich (August: $121 \mathrm{mg} \mathrm{m}^{-2}$ ), followed by oligotrophic Lake Lucerne (August: 75, September: $34 \mathrm{mg} \mathrm{m}^{-2}$ ) and mesotrophic Lake Cadagno (August: 33, September: 25 and $14 \mathrm{mg} \mathrm{m}^{-2}$ ), and (iv) areal primary production was highest in Lake Zürich (August: 105, September: $124 \mathrm{mg} \mathrm{C} \mathrm{m}^{-2} \mathrm{~h}^{-1}$ ), followed by Lake Cadagno (August: 102, September: $52 \mathrm{mg} \mathrm{C} \mathrm{m}^{-2} \mathrm{~h}^{-1}$ ) and Lake Lucerne (August: 90, September: $52 \mathrm{mg} \mathrm{C} \mathrm{m}^{-2}$ $\mathrm{h}^{-1}$ ). Physiological parameters, determined in situ from $P$ versus $I$ relationships, showed a lower initial slope $\alpha$ in Lake Lucerne (August: 0.03, September: $0.02 \mathrm{mg} \mathrm{C} \mathrm{mg}^{-1} \mathrm{chl} a \mathrm{~h}^{-1} \mu \mathrm{mol}^{-1} \mathrm{~m}^{2} \mathrm{~s}$ ) than in the other two lakes (Lake Zürich in August: 0.05, in September: 0.11; Lake Cadagno in August: 0.05 , in September: 0.11 and $0.28 \mathrm{mg} \mathrm{C} \mathrm{mg}^{-1} \mathrm{chl} a \mathrm{~h}^{-1} \mu \mathrm{mol}^{-1} \mathrm{~m}^{2} \mathrm{~s}$ ). Lake Zürich showed the lowest $A N_{\max }$ (August: 2.6, September: $3.2 \mathrm{mg} \mathrm{C} \mathrm{mg}^{-1} \mathrm{chl} a \mathrm{~h}^{-1}$, as compared to $5.9-7.4 \mathrm{mg} \mathrm{C} \mathrm{mg}^{-1} \mathrm{chl} a$ $\mathrm{h}^{-1}$ in the Lakes Lucerne and Cadagno), while in Lake Cadagno the highest inhibitory effects of $\mathrm{C}$ assimilation were found (highest slopes of inhibition $\beta, 0.007-0.011$, as compared to $0.0003-0.0026$ in the other two lakes), due to a higher UV-exposure in this alpine lake.
\end{abstract}

* Corresponding author, e-mail: peter.bossard@eawag.ch 


\section{Introduction}

The Lakes Lucerne, Zürich and Cadagno (Fig. 1) were chosen as sites of investigation for the $7^{\text {th }}$ International GAP Workshop (9-17 September 1999) on the dynamics of primary production in spatially and temporally heterogeneous aquatic environments. All sampling sites are easily accessible and backed up by well equipped field stations nearby. Furthermore, a large variety of limnological data is available about these lakes, which differ in their altitudes and thus in the proportion of UV radiation of the total irradiance, but also in the underwater light climate, chemical composition, trophic state and the diversity of the plankton community.

Figure 1 shows the outlines of the three lakes with the sampling sites used during the GAP Workshop. The fjordlike lake system of Lake Lucerne in the Swiss prealpine calcareous region and the trough-shaped Lake Zürich in the moraineous sedimentary lowland are relatively large and deep lakes. Lake Cadagno is a small bowlshaped basin in an alpine valley of the crystalline mountain range, whose bedrock contains dolomite and gypsum. All three lakes are mainly of glacial origin. Lake Cadagno is covered with ice up to two meters thick each winter, while the Lakes Lucerne and Zürich hardly ever freeze.


Figure 1. Lakes Lucerne, Zürich and Cadagno with field stations and sampling sites in the GAPWorkshop 1999 
Table 1. Limnological description of the Lakes Lucerne, Zürich and Cadagno

a) Geographical and physical characterization:

\begin{tabular}{llclccll}
\hline Lake & $\begin{array}{l}\text { region, } \\
\text { catchment }\end{array}$ & $\begin{array}{l}\text { altitude } \\
\text { (m a.s.l.) }\end{array}$ & $\begin{array}{l}\text { max. } \\
\text { depth } \\
{[\mathrm{m}]}\end{array}$ & $\begin{array}{l}\text { mean } \\
\text { depth } \\
{[\mathrm{m}]}\end{array}$ & $\begin{array}{l}\text { surface } \\
\text { area } \\
{\left[\mathrm{km}^{2}\right]}\end{array}$ & $\begin{array}{l}\text { residence } \\
\text { time } \\
\text { [years] }\end{array}$ & \\
\hline Zürich & lowland & 406 & 136 & 51 & 68 & 1.4 & monomictic \\
Lucerne & pre-alpine & 434 & 214 & 104 & 113 & 3.4 & $\begin{array}{l}\text { monomictic } \\
\text { meromictic }\end{array}$ \\
Cadagno & alpine & 1921 & 20 & 9 & 0.27 & n.d & \\
\hline
\end{tabular}

b) Limnological characterization of the epilimnion

\begin{tabular}{|c|c|c|c|c|c|c|c|c|c|}
\hline Lake & trophic state & \multicolumn{2}{|c|}{$\begin{array}{l}P_{\text {tot }} \\
{\left[\mu g 1^{-1}\right]}\end{array}$} & \multicolumn{2}{|c|}{$\begin{array}{l}\mathrm{NO}_{3}-\mathrm{N} \\
{\left[\mu \mathrm{g} \mathrm{l}^{-1}\right]}\end{array}$} & \multicolumn{2}{|c|}{$\begin{array}{l}\text { annual APP } \\
{\left[\mathrm{g} \mathrm{C} \mathrm{m}^{-2} \mathrm{y}^{-1}\right]}\end{array}$} & $\begin{array}{l}\text { APP in } \\
\text { summer } \\
{\left[\mathrm{mg} \mathrm{C} \mathrm{m}^{-2} \mathrm{~h}^{-1}\right]}\end{array}$ & $\begin{array}{l}{ }^{*} \mathrm{Chl} a \text { in } \\
\text { summer } \\
1]\left[\mathrm{mg} \mathrm{m}^{-2}\right]\end{array}$ \\
\hline $\begin{array}{l}\text { Zürich } \\
\text { Lucerne } \\
\text { Cadagno }\end{array}$ & $\begin{array}{l}\text { mesotrophic } \\
\text { oligotrophic } \\
\text { mesotrophic }\end{array}$ & $\begin{array}{l}* * 3 \\
* * 6 \\
x<\end{array}$ & $\begin{array}{l}4 \pm 10 \\
5 \pm 1.7 \\
0\end{array}$ & $\begin{array}{l}* * 78 \\
* * 59 \\
x x x<5\end{array}$ & $\begin{array}{l}52 \\
37\end{array}$ & $\begin{array}{l}* 217 \pm \\
+176 \pm \\
\text { n.d. }\end{array}$ & & $\begin{array}{r}* 100 \pm 59 \\
+73 \pm 30 \\
\times x 54 \pm 19\end{array}$ & $\begin{array}{r}* 133 \pm 60 \\
+73 \pm 32 \\
x x 36 \pm 14\end{array}$ \\
\hline Lake & $\begin{array}{l}\text { Secchi depth } \\
\text { summer }[\mathrm{m}]\end{array}$ & & $\begin{array}{l}\text { Con } \\
{[\mu \mathrm{S} \mathrm{c}}\end{array}$ & ity & & & & $\left.\mathrm{Cl}^{-1}\right]$ & $\begin{array}{l}\text { Silicate } \\
{\left[\mathrm{mg} \mathrm{SiO}_{2} \mathrm{l}^{-1}\right]}\end{array}$ \\
\hline $\begin{array}{l}\text { Zürich } \\
\text { Lucerne } \\
\text { Cadagno }\end{array}$ & $\begin{array}{l}* 4.4 \pm 1.7 \\
* 5.8 \pm 1.4 \\
+6.8 \pm 0.6\end{array}$ & & $\begin{array}{l}* * 260 \\
* * 203 \\
\times 160-3\end{array}$ & & $\begin{array}{l}* * 32 \\
* * 23 \\
\times \text { app. }\end{array}$ & $\begin{array}{l} \pm 1.7 \\
\pm 1.2 \\
10\end{array}$ & $\begin{array}{r}* 1 \\
* * 0 \\
\text { xapp }\end{array}$ & $\begin{array}{l}2 \pm 0.2 \\
9 \pm 0.1 \\
\text { p. } 1.5-2\end{array}$ & $\begin{array}{l}* * 2.9 \pm 0.3 \\
* * 2.2 \pm 0.3 \\
\text { *app. } 1\end{array}$ \\
\hline
\end{tabular}

c) Phytoplankton communities

\begin{tabular}{|c|c|c|}
\hline Lake & dominating algae in winter & dominating algae/bacteria in summer \\
\hline Zürich & $\begin{array}{l}\text { Planktothrix rubescens, centric } \\
\text { diatoms }\end{array}$ & $\begin{array}{l}\text { pennate diatoms, Dinobryon, } \\
\text { Cryptomonas, } P \text {. rubescens (metalimnion) }\end{array}$ \\
\hline Lucerne & Rhodomonas, centric diatoms & $\begin{array}{l}\text { pennate diatoms, chrysophytes, } \\
\text { cryptophytes }\end{array}$ \\
\hline Cadagno & n.d., under ice cover & $\begin{array}{l}\text { diatoms, chlorophytes, cyanobacteria, } \\
\text { phototrophic sulfur bacteria }\end{array}$ \\
\hline
\end{tabular}

Averages \pm standard deviation. * Average 1990-1999 (**at full circulation); ${ }^{+}$Average 1990-1997. ${ }^{x}$ estimation based on recent sampling campaigns in summer (Peduzzi at al., 1998). ${ }^{x x}$ Average of a sampling campaign in summer 1986 (by Friedl, 1987). ${ }^{x x}$ Average of a sampling campaign in 1984/85 (by Del Don, 1986)

Table 1 gives a short overview on some limnological characteristics of the three lakes. Details about the long term development of the lakes are published elsewhere (for Lake Lucerne see Bührer and Ambühl, 1996 and 2001; Bürgi et al., 1999; Bloesch et al., 1995; for Lake Zürich: Gammeter et al., 1997; Gammeter and Zimmermann, 2001; Schanz, 1994; for Lake Cadagno: Peduzzi et al., 1998).

This article provides information for better understanding the results of the works achieved during the GAP VII Workshop published in this special issue. We also describe limnological key parameters and basic techniques of their assessment and analysis. The limnological situation of the three lakes, relevant for primary pro- 
duction in summer 1999 (before and during the GAP-Workshop), is presented. A thorough orographical, biogeochemical and microbial description of Lake Cadagno is given in a separate article by Del Don et al. (2001).

\section{Materials and methods}

Vertical profiles of limnological key parameters, such as temperature, $\mathrm{pH}$, alkalinity, DIC, $\mathrm{O}_{2}, \mathrm{PO}_{4}-\mathrm{P}$, total $\mathrm{P}, \mathrm{NO}_{3}-\mathrm{N}, \mathrm{SiO}_{2}$, underwater light regime, and ${ }^{14} \mathrm{C}$-assimilation, were assessed in the euphotic zones of the three lakes before (in August 1999) and during the workshop (in the period from 10 to 14 of September 1999).

\section{Physical factors}

Under water light regimes: Photosynthetically available radiation (PAR) was measured in $\mu \mathrm{mol} \mathrm{m} \mathrm{m}^{-2} \mathrm{~s}^{-1}$ with a scalar quantum sensor (LI $190 \mathrm{SB}$ ) connected to an integrating quantum meter (LI 188) made by LI-COR Inc, USA. A second sensor served as a reference, measuring PAR simultaneously above the water surface. The measurements were corrected for the immersion effect. Ultraviolet radiation (UV-A, UV-B) was assessed in $\mu \mathrm{W} \mathrm{cm}^{-2}$ with flat cosine corrected sensors (SD 104/UV-A and SD 104/UV-B) of the same type as used for measuring surface radiation. The inherent difference between the two sensor types, the PAR sensor measures photons while the UV sensors measure energy, impedes a precise direct comparison of the two types of measurement. The vertical light attenuation coefficient $\left(K_{\mathrm{d}}\right)$ was calculated using the formula presented by Schanz (1985). After linearisation the slope $\left(=\right.$ vertical light attenuation coefficent, $\left.\mathrm{m}^{-1}\right)$ was calculated by the least square method.

Surface radiation: During the GAP Workshop PAR was measured at the three experimental sites; for Lake Cadagno at the Biological Alpine Station Piora, for Lake Lucerne at the Lake Research Institute, and for Lake Zürich on the roof of Sprüngli Factory (near the Limnological Station, Kilchberg) and on the roof of the City of Zürich Water Supply building at Lengg. UV-A and UV-B were continuously monitored at the field stations near the sampling site. Integrators (LI 1000, LICOR) yielded a continuous output of PAR, and/or UVR integrals over intervals of 10 min. We used cosine corrected PAR sensors (LI 190), and cosine corrected UV sensors (SD 104/UV-A and SD 104/UV-B). For more technical details and comparison of instruments: see Neale et al. (2001 b, this issue).

\section{Temperature, conductivity, turbidity and oxygen}

In Lake Lucerne temperature and conductivity were measured in situ with a WTW probe (Conductometer LF 191, Weinheim, Germany). Dissolved oxygen was determined with the Winkler method modified by Carpenter (1965).

In Lake Cadagno profiles ( $0-21 \mathrm{~m})$ were measured routinely for temperature, conductivity, dissolved oxygen and turbidity using the YSI 6920 multisonde (Yellow Springs Instruments, USA). 
In Lake Zürich temperature was measured in situ with a digital thermometer (DMP, Switzerland) connected to a LI 1000 datalogger (LI-COR Inc., USA.), dissolved oxygen was determined as in Lake Lucerne, conductivity was measured in bottled water samples in the laboratory (with a Conductometer E518, Metrohm, Switzerland).

\section{Chemical parameters}

Alkalinity was titrated according to Standard Methods (1971). Dissolved inorganic carbon (DIC) was determined from alkalinity and $\mathrm{pH}$ according to Rodhe (1958) and Goltermann et al. (1978).

In Lake Lucerne water samples, ortho-phosphate (SRP) and total phosphorus $\left(\mathrm{P}_{\text {tot }}\right)$ were analyzed with the molybdenum blue method according to Vogler (1965) and Schmid and Ambühl (1965).

Ammonia $\left(\mathrm{NH}_{4}-\mathrm{N}\right)$, nitrate $\left(\mathrm{NO}_{3}-\mathrm{N}\right)$ and nitrite $\left(\mathrm{NO}_{2}-\mathrm{N}\right)$ were determined colorimetrically according to DEV (1985). Silicate $\left(\mathrm{SiO}_{2}\right)$ was analyzed with the heteropoly blue method (APHA 1989). Sulfate $\left(\mathrm{SO}_{4}\right)$ was determined according to DEW 1996.

In Lake Cadagno water samples, SRP and $\mathrm{P}_{\text {tot }}, \mathrm{NH}_{4}-\mathrm{N}$ and $\mathrm{NO}_{2}-\mathrm{N}$ were determined colorimetrically according to DEV (1972), $\mathrm{NO}_{3}-\mathrm{N}$ photometrically at $220 \mathrm{~nm}$ (Standard Methods, 1975), sulfide $\left(\mathrm{H}_{2} \mathrm{~S}\right)$ according to Gilboa-Garber (1971), $\mathrm{SO}_{4}$ with anion chromatography (ion exchange column Wescan W-498) according to Hanselmann and Hutter (1998).

In Lake Zürich water samples, $\mathrm{SRP}$ and $\mathrm{P}_{\text {tot }}$ were determined according to DIN/EN1189 (DEW 1996), $\mathrm{NO}_{3}-\mathrm{N}$ according to DIN/EN/ISO 10304-1 (DEW 1996), and $\mathrm{SiO}_{2}$ according to DIN 38405 (DEW 1996).

\section{Biological parameters}

Phytoplankton: Samples from different depths (Lake Zürich, Lake Cadagno) or integrated samples from 0-20 m (Lake Lucerne) or 0-15 m (Lake Cadagno) were immediately fixed with Lugol solution. The biovolume of phytoplankton genera and species was obtained by counting and measuring cells by means of an inverted microscope (Utermöhl, 1958). Results of fresh weight (FW) given in this paper are determined from biovolumes, using a specific weight factor of 1.0.

Chlorophyll: In Lake Lucerne and Lake Cadagno, sample preparation and chlorophyll extraction was performed according to DEV, 1986: Samples were filtered through Whatman GF/F filters. The filters were put into Sovirel tubes filled with $8 \mathrm{ml}$ of $90 \%$ ethanol. Chlorophyll was extracted by heating the samples (for $10 \mathrm{~min}$ ) in a water bath at $75^{\circ} \mathrm{C}$ and subsequent sonification (for $5 \mathrm{~min}$ ) at room temperature. Before HPLC analysis the chlorophyll extracts were filtered through Millipore Millex FG $0.2 \mu \mathrm{m}$ membrane filters. Chlorophyll species were determined according to Meyns et al. (1994) and Murray et al. (1986): Chlorophyll $a$ and $b$ were separated isocratically by HPLC at a flux rate of $1.0 \mathrm{ml} \mathrm{min}^{-1}$ in a mixture of $49.5 \%$ methanol, $45 \%$ ethyl acetate and $5.5 \%$ water, and quantified with photometric detectors at $430 \mathrm{~nm}$ (for $\operatorname{chl} a$ ) and $460 \mathrm{~nm}$ (for $\operatorname{chl} b$ ). 
In Lake Zürich, samples were filtered through Whatman GF/F filters and the filters immediately stored at $-20^{\circ} \mathrm{C}$. The filters then were homogenised in $10 \mathrm{ml} 90 \%$ acetone. The chlorophyll extracts were filtered through Whatman GF/F filters. Chlorophyll $a, b$ and $c$ and up to 15 carotenoids were separated by a quaternary HPLC column at a flux rate of $1.0 \mathrm{ml} \mathrm{min}^{-1}$ and determined by their spectra between 350 and $600 \mathrm{~nm}$.

Primary Production (PP; ${ }^{14} \mathrm{C}$-Assimilation, in $\mathrm{mg} \mathrm{C} \mathrm{m}{ }^{-3} \mathrm{~h}^{-1}$ ): Water samples were taken at $0.2,0.5,1,1.5,2.5,3.75,5,7.5,10,12.5,15$, and 20 meters depth, and in situ measurements were performed in $120 \mathrm{ml}$ Duran bottles (transmission properties, see Köhler et al., this issue) at each specific depth. Incubations took place for four hours from 10 to $14 \mathrm{~h}$ local time (CET), after addition of $5-10 \mu \mathrm{Ci} \mathrm{NaH}{ }^{14} \mathrm{CO}_{3}$ per bottle. From each of the samples taken in the Lakes Lucerne and Cadagno between 0.2 and 5 meters, sub-samples were incubated in situ in Duran bottles covered with a UV-screen (transparent hard PVC tube according to Bühlmann et al., 1987) to measure the difference in ${ }^{14} \mathrm{C}$-assimilation, when $\mathrm{UV}$ radiation is removed. After incubation, the ${ }^{14} \mathrm{C}$ samples were immediately transported to the field station and processed by the acidic bubbling method, according to Gächter and Mares (1979). Radioactivity was determined in liquid scintillation counters (Model Tricarb, Packard, USA.), after addition of $10 \mathrm{ml}$ of Instagel ${ }^{\mathrm{TM}}$ (Packard, USA.) to $7 \mathrm{ml}$ water sample in glass vials of $20 \mathrm{ml}$ volume. The glass quality of the bottles used in Lake Zürich for the in situ incubation on 4 August 1999 was less transparent to UV (93\% absorption at $325 \mathrm{~nm}, 40 \%$ at $350 \mathrm{~nm}$ ) than the Duran bottles (22\% absorption at $325 \mathrm{~nm}, 4 \%$ at $350 \mathrm{~nm})$.

The Specific Photosynthetic Rate (SPP, often defined as $P^{\mathrm{B}}$ or Assimilation Number $A N)$ was calculated as C-assimilation per chlorophyll $a\left[\mathrm{mg} \mathrm{C}(\operatorname{mg} \operatorname{chl} a)^{-1}\right.$ $\mathrm{h}^{-1}$. $P$ versus $I$ curves were calculated with a least square fit of the mathematical equation (Platt et al., 1980):

$$
P^{\mathrm{B}}=P_{\mathrm{S}}^{\mathrm{B}}\left(1-e^{-\frac{\alpha \cdot I}{P_{\mathrm{S}}^{\mathrm{B}}}}\right) e^{-\frac{\beta \cdot I}{P_{\mathrm{S}}^{\mathrm{B}}}}\left(\text { or shorter: } P^{\mathrm{B}}=P B S\left(1-e^{-\alpha \mathrm{I} / \mathrm{PBS}}\right) e^{-\beta \mathrm{I} / \mathrm{PBS}}\right)
$$

where $P^{\mathrm{B}}$ is gross primary productivity per unit biomass (in $\left.\mathrm{mg} \mathrm{C} \cdot(\mathrm{mg} \mathrm{chl} a)^{-1} \cdot \mathrm{h}^{-1}\right)$, and $I$ is the ambient light intensity $\left(\mu \mathrm{mol} \mathrm{m} \mathrm{m}^{-2} \mathrm{~s}^{-1}\right)$. In this paper $P_{\mathrm{S}}^{\mathrm{B}}$ and $A N_{\max }$ are not identical. $P_{\mathrm{S}}^{\mathrm{B}}(\mathrm{PBS})$ was calculated by curve fitting as the hypothetical maximum photosynthetic output the algae could sustain if there were no photoinhibition, while $A N_{\max }$ was determined in situ as the maximum $A N$ measured in bottle samples at light saturation protected from exposure to UV radiation by filter screens.

The coefficient $\alpha\left(\mathrm{mg} \mathrm{C}(\mathrm{mg} \mathrm{chl} a)^{-1} \mathrm{~h}^{-1}\left(\mu \mathrm{mol} \mathrm{m}{ }^{-2} \mathrm{~s}^{-1}\right)^{-1}\right)$, the slope of the linear part of the $P$ versus $I$ curve, is the increase of $A N$ per unit increase in $I$ that is in effect at $I=0$ (initial slope) in the absence of photoinhibition. The coefficient $\beta$ (dimensionless) is the fractional decrease in $P^{\mathrm{B}}$ caused by photoinhibition.

$P_{\mathrm{s}}^{\mathrm{B}}, \alpha$, and $\beta$ were determined by curve fitting by two approaches: Because a simultaneous calibration of the coefficients $\alpha, \beta$ and $P_{\mathrm{s}}^{\mathrm{B}}$ yielded sometimes unrealistic values, they were also calibrated stepwise: $\alpha$ was first determined with equation $P^{\mathrm{B}}=P B S\left(1-e^{-\alpha \mathrm{I} / \mathrm{PBS}}\right)$ from datasets containing only low light intensity data; $\beta$ was 
then determined with equation $P^{\mathrm{B}}=P B S e^{-\beta \mathrm{I} / \mathrm{PBS}}$ from datasets containing only high light intensity data. $P B S$ was thereafter calibrated with the full dataset with Platt's equation $\left(P^{\mathrm{B}}=P B S\left(1-e^{-\alpha \mathrm{I} / \mathrm{PBS}}\right) e^{-\beta \mathrm{I} / \mathrm{PBS}}\right)$ where $\alpha$ and $\beta$ were kept as fixed constants.

\section{Characteristics of the lakes investigated}

\section{Lake Lucerne}

Lake Lucerne (Vierwaldstättersee) is an oligotrophic deep prealpine monomictic lake of a complicated morphological structure consisting of a chain of different basins. Chemical, physical and biological parameters have been monitored in monthly intervals from 1961 to 1992 (Bührer and Ambühl, 1996 and 2001) and since then twice per year (plankton monthly). Primary production (PP) has been assessed monthly from 1979 until 1997 . Size related primary production was investigated by Uehlinger and Bloesch (1989).

The lake was originally oligotrophic. Between 1960 and 1980 it underwent a period of eutrophication which reached a peak in the late seventies (total $\mathrm{P}$ at maximum spring turnover: $30 \mathrm{mg} \mathrm{m}^{-3}$, annual Areal Primary Production (APP): $300 \mathrm{~g} \mathrm{C}$ $\left.\mathrm{m}^{-2} \mathrm{yr}^{-1}\right)$. Subsequently the lake turned from mesotrophic to oligotrophic again (total $\mathrm{P}$ at maximum spring turnover $<5 \mathrm{mg} \mathrm{m}^{-3}$, annual APP $<200 \mathrm{~g} \mathrm{C} \mathrm{m}^{-2} \mathrm{yr}^{-1}$ ) within 15 years, due to a reduction of the phosphorus load from 103 to $14 \mathrm{t} \mathrm{yr}^{-1}$ (Bloesch et al., 1995). Nitrate as the major component of total dissolved nitrogen, however, continued to increase (measured at maximum spring turnover) from $340 \mu \mathrm{g} \mathrm{N} \mathrm{l}^{-1}$ in 1960 to 600 in 1999.

The long-term development of phytoplankton is described in detail by Bürgi et al. (1999 and 1985). In the 1960s the phytoplankton community was dominated by cyanophytes (mainly Planktothrix rubescens) and pennate diatoms. The chlorophytes were rare. With increasing P-load the green algae added some distinct peaks, but diatoms (shifting from pennate to centric forms) and blue-greens remained dominant. At the peak of eutrophication (in the late seventies) chlorophytes were also abundant, while the Planktothrix biomass declined. During the phase of pronounced oligotrophication (1982-85) the biomass of cyanophytes decreased to minor densities, as well as diatoms, dinophytes and cryptomonads, while chrysomonads and green algae remained stable. Later on (1986-95) the phytoplankton composition tended to shift from netplankton to motile nannoplankton, e.g. towards small flagellates (Chrysophyceae). Planktothrix rubescens also recovered while the green algae decreased.

Today the community structure is dominated in winter by Rhodomonas and centric diatoms, in summer by pennate diatoms (Fragilaria) and in autumn by bluegreens, e.g. Planktothrix rubescens (Bürgi et al., 1999).

The euphotic zone ( $>1 \%$ of surface PAR) expanded during re-oligotrophication from $15 \mathrm{~m}$ (in 1980) to $20 \mathrm{~m}$ (in 1999), thus considerably enlarging the layer of primary production. This may be one reason for an only moderate decrease of pelagic primary productivity in spite of the drastic decrease of SRP during that period. 
Key parameters measured in summer 1999

Figure 2 presents a summary of the two sampling days on 25 August and 13 September 1999.

The summer 1999 was very rainy at the beginning, but ended with a warm, dry period in September. Compared to other years this resulted in a relatively low energy input into the lake until end of August. However, while in former years the upper lake epilimnion had already cooled down by mid-September, water temperatures were still rising in the first part of September 1999. During the GAP-Workshop (13 September) the epilimnion was stratified as reflected by an almost linear temperature decrease from $19.4^{\circ} \mathrm{C}$ at $2.5 \mathrm{~m}$ to $8.5^{\circ} \mathrm{C}$ in $20 \mathrm{~m}$ depth (Fig. $2 \mathrm{a}$ ). Within the uppermost 2.5 meters the temperature difference was small $\left(0.4^{\circ} \mathrm{C}\right)$.

While there was still plenty of nitrate $\left(230-330 \mathrm{\mu g} \mathrm{NO}_{3}-\mathrm{N} \mathrm{l}^{-1}\right)$ and silicate (430$1650 \mu \mathrm{g} \mathrm{SiO}_{2} \mathrm{l}^{-1}$ ) available (Figs. 2e,f), the growth-limiting nutrient SRP (Fig. 2d) was hardly detectable $\left(0-1 \mu \mathrm{g} \mathrm{P}^{-1}\right)$ within the whole epilimnion.

The euphotic zone ( $>1 \%$ of surface PAR) extended to a depth of $15.1 \mathrm{~m}$ during the GAP Workshop (Fig. $2 \mathrm{~g}_{1}$ ). $10 \%$ of the surface radiation were measured on 13 September for PAR at a depth of $7.1 \mathrm{~m}\left(K_{\mathrm{d}, \mathrm{PAR}}=0.313 \mathrm{~m}^{-1}\right)$, for UV-A at $3.7 \mathrm{~m}$ $\left(K_{\mathrm{d}, \mathrm{UV}-\mathrm{A}}=0.618 \mathrm{~m}^{-1}\right)$, and for UV-B at $2.1 \mathrm{~m}\left(K_{\mathrm{d}, \mathrm{UV}-\mathrm{B}}=1.047 \mathrm{~m}^{-1}\right)$ (see Figs. $2 \mathrm{~g}, \mathrm{~h}, \mathrm{j}$, and Table 2). Good weather conditions with frequent cloudless periods during the GAP Workshop resulted in relatively high surface radiation intensities, which produced ideal conditions to assess the full scale of inhibition, saturation and light limitation within in situ PP depth profiles (Fig. 21).

The phytoplankton community was dominated in August and September 1999 by chrysophytes (Dinobryon, Erkenia, Ochromas sp.) and diatoms (Asterionella, Fragilaria, Synedra, Cyclotella, Stephanodiscus). A sharp decline of pennate diatoms from 30 August to 7 September was compensated by an increase in centric diatoms (Fig. 3).

Both parameters for phytoplankton biomass, fresh weight and chlorophyll $a$, decreased in the period immediately before the GAP Workshop (Table 2, Fig. 3).

The depth profiles of primary production (PP) of 25 August and 13 September (Fig. 2), determined at full sunshine, showed typical near surface depressions. The production maxima were between 3.75 and 5.0 (on 13 September) and between 5 and $7.5 \mathrm{~m}$ depth (on 25 August), respectively, which corresponds approximately to the chlorophyll maxima in those depths.

Table 2. Lake Lucerne, key parameters for primary production in summer 1999

\begin{tabular}{|c|c|c|c|c|c|c|c|}
\hline Date & $\begin{array}{l}\text { Surface } \\
\text { PAR I } \\
{\left[\mu \mathrm{mol}_{0}\right.} \\
\left.\mathrm{m}^{-2} \mathrm{~s}^{-1}\right]\end{array}$ & $\begin{array}{l}10 \% \text { of } \\
\text { surface } \\
\text { PAR, } \\
\text { depth }[\mathrm{m}]\end{array}$ & $\begin{array}{l}\text { Phyto- } \\
\text { plankton } \\
0-20 \mathrm{~m} \\
{\left[\mathrm{~g} \mathrm{FW} \mathrm{m}^{-2}\right]}\end{array}$ & $\begin{array}{l}\text { Chl } a \\
0-20 \mathrm{~m} \\
{\left[\mathrm{mg} \mathrm{m}^{-2}\right]}\end{array}$ & $\begin{array}{l}\text { Chl } b \\
0-20 \mathrm{~m} \\
{\left[\mathrm{mg} \mathrm{m}^{-2}\right]}\end{array}$ & $\begin{array}{l}\text { APP } \\
0-20 \mathrm{~m}^{-2} \\
{\left[\mathrm{mg} \mathrm{C} \mathrm{m}^{-2}\right.} \\
\left.\mathrm{h}^{-1}\right]\end{array}$ & $\begin{array}{l}\text { AN } \\
\text { ave. } 0-5 \mathrm{~m} \\
{[\mathrm{mg} \mathrm{C}(\mathrm{mg}} \\
\left.\operatorname{chl} a)^{-1} \mathrm{~h}^{-1}\right]\end{array}$ \\
\hline $\begin{array}{l}16-08-99 \\
25-08-99 \\
30-08-99\end{array}$ & 1273 & 8.7 & $\begin{array}{l}15.5 \\
16.3\end{array}$ & 78.7 & 1.96 & 90.2 & $2.15 \pm 0.76$ \\
\hline $\begin{array}{l}07-09-99 \\
13-09-99\end{array}$ & 1010 & 7.1 & 7.4 & 34.5 & 1.88 & 52.1 & $3.89 \pm 2.12$ \\
\hline
\end{tabular}



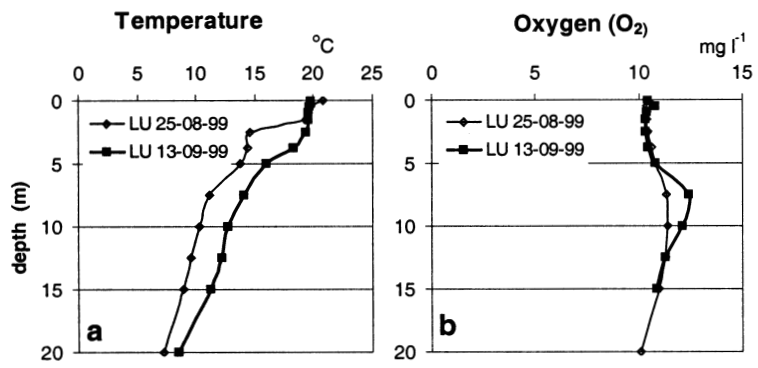

\section{Total inorganic Carbon}

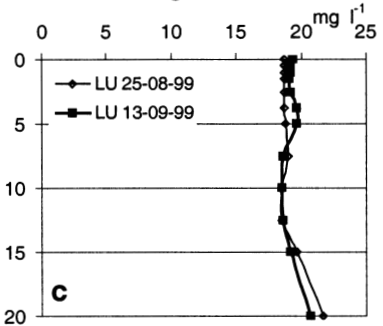

Phosphorus

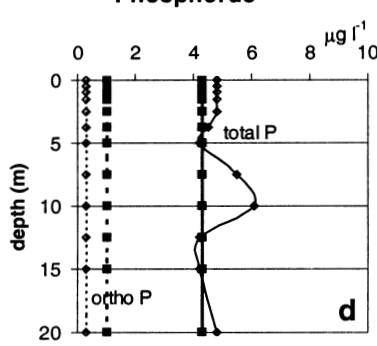

Nitrate $\left(\mathrm{NO}_{3}-\mathrm{N}\right)$

Silicate $\left(\mathrm{SiO}_{2}\right)$
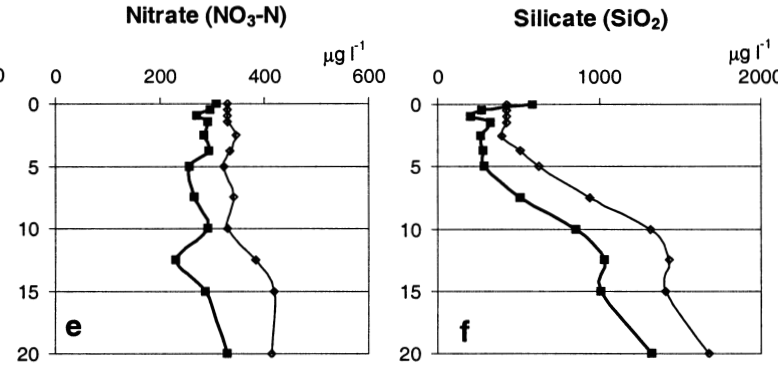

PAR in $\%$ of $\mathrm{I}_{\text {。 }}$
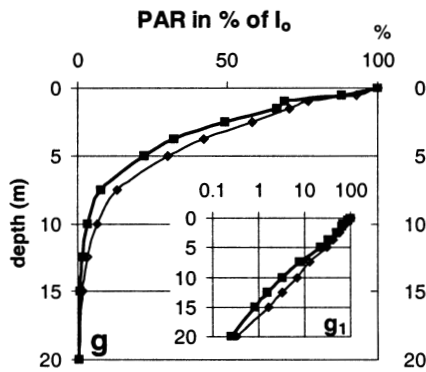

UV-A in \% of $I_{0}$
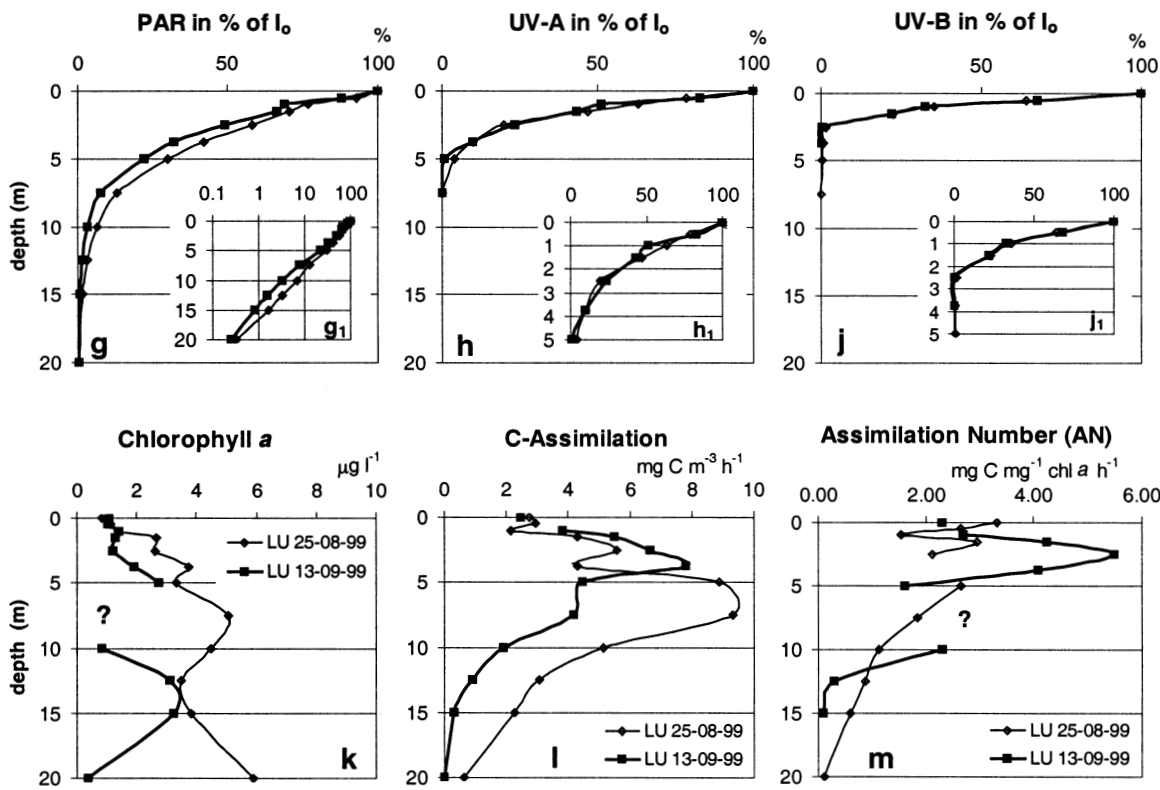

\section{Assimilation Number (AN)}



Figure 2. Lake Lucerne, Kreuztrichter, depth profiles of 25 August (diamonds) and 13 September (squares) 1999, for (a) temperature, (b) oxygen, (c) total dissolved inorganic carbon (DIC), (d) ortho-phosphate (SRP) and total-phosphorus $\left(\mathrm{P}_{\text {tot }}\right)$, (e) nitrate, (f) silicate, (g) PAR transparency in percent of incident radiation at the water surface, with inset $\left(g_{1}\right) \log$ representation, (h) UV-A transparency with inset $h_{1}$ ) zoom of the uppermost five meters, (j) UV-B transparency with inset $\left(\mathrm{j}_{1}\right)$ zoom, (k) chlorophyll $a$, (l) photosynthetic C-assimilation, and (m) chlorophyllspecific C-assimilation (assimilation number, $\mathrm{AN}$ ) 


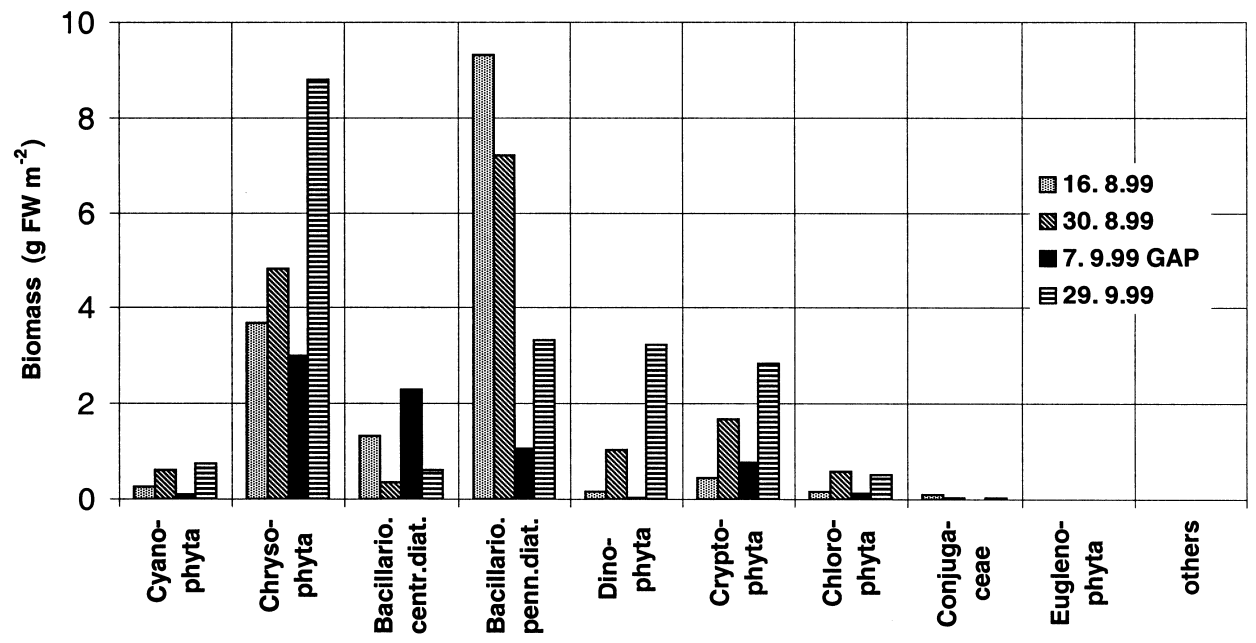

Figure 3. Phytoplankton community structure in the trophogenic layer $(0-20 \mathrm{~m})$ of Lake Lucerne, Kreuztrichter, of 16 August, 30 August, 7 September, and 29 September 1999; biomass in $\mathrm{g} \mathrm{FW} \mathrm{m}{ }^{-2}$

The profiles of $A N$ showed equal shapes of curves. However, the maximum $A N$ were closer to the surface than those of PP, namely between 2.5 and $3.75 \mathrm{~m}$ depth at both days. In the period of 1995-1997, when C-assimilation was measured monthly, $A N$ never rose above $4 \mathrm{mg} \mathrm{C} \mathrm{mg}^{-1} \mathrm{chl} a \mathrm{~h}^{-1}$ at any depth at any season. The Assimilation Numbers in the depths of $1.5 \mathrm{~m}(A N$ of 7.2$)$ and $2.5 \mathrm{~m}(A N$ of 5.5$)$ seem to be quite high (Fig. $2 \mathrm{~m}$ ) due to low chl $a$ values. They fit, however, into the general picture obtained from long term data of past years that $A N$ values tend to increase in late summer and early fall.

\section{Lake Zürich}

Lake Zürich is a deep, and based on the sediments (Züllig, 1982), an originally oligotrophic lake in a densely populated region. It suffered from sewage discharges since the beginning of the $20^{\text {th }}$ century (Thomas, 1965). The lake has been monitored intensively for many decades as it serves as a major source for drinking water production. In the period from 1937 to 1975 chemical and physical measurements have been done routinely at several sites along the length axis of the lake by the Cantonal Laboratory Zürich (Oern, 1980). During the past 25 years monthly profiles of chemical, physical and biological parameters, in particular phytoplankton and primary productivity, have been measured by Zürich Water Supply (Gammeter et al., 1997).

Since 1955 over $90 \%$ of the population around the lake have been connected to wastewater treatment plants with enhanced P-removal (today eliminating up to $99 \%$ of total P). As a result, Lake Zürich returned from an eutrophic (Total P, TP, at maximum spring overturn $>100 \mu \mathrm{g} \mathrm{l^{-1 }}$ around 1970) to a mesotrophic state with 
Table 3. Lake Zürich, key parameters for primary production in summer 1999

\begin{tabular}{|c|c|c|c|c|c|c|c|}
\hline Date & $\begin{array}{l}\text { Surface } \\
\text { PAR I } \\
{[\mu \mathrm{mol}} \\
\left.\mathrm{m}^{-2} \mathrm{~s}^{-1}\right]\end{array}$ & $\begin{array}{l}10 \% \text { of } \\
\text { surface } \\
\text { PAR, } \\
\text { depth }[\mathrm{m}]\end{array}$ & $\begin{array}{l}\text { Phyto- } \\
\text { plankton } \\
0-15 \mathrm{~m} \\
{\left[\mathrm{~g} \mathrm{FW} \mathrm{m}^{-2}\right]}\end{array}$ & $\begin{array}{l}\text { Chl } a \\
0-15 \mathrm{~m} \\
{\left[\mathrm{mg} \mathrm{m}^{-2}\right]}\end{array}$ & $\begin{array}{l}\text { Chl } b \\
0-15 \mathrm{~m} \\
{\left[\mathrm{mg} \mathrm{m}^{-2}\right]}\end{array}$ & $\begin{array}{l}\text { APP } \\
0-15 \mathrm{~m} \\
{\left[\mathrm{mg} \mathrm{C} \mathrm{m}^{-2}\right.} \\
\left.\mathrm{h}^{-1}\right]\end{array}$ & $\begin{array}{l}\text { AN } \\
\text { ave. } 0-5 \mathrm{~m} \\
{[\mathrm{mg} \mathrm{C}(\mathrm{mg}} \\
\left.\operatorname{chl} a)^{-1} \mathrm{~h}^{-1}\right]\end{array}$ \\
\hline 04-08-99 & 1251 & 3.7 & 43.9 & 104.5 & 3.5 & & $2.12 \pm 0.35$ \\
\hline $18-08-99$ & 180 & 5.0 & 28.0 & n.d. & n.d. & n.d. & n.d. \\
\hline 08-09-99 & 1245 & 4.9 & 42.4 & 65.6 & 2.35 & 124.5 & $2.71 \pm 0.53$ \\
\hline
\end{tabular}

TP concentrations of $30 \mu \mathrm{g} \mathrm{l}^{-1}$. A first report on the oligotrophication of Lake Zürich was given by Schanz and Thomas (1981). P load is relatively stable since 1990. During the past 10 years the annual APP was $217 \mathrm{~g} \mathrm{C} \mathrm{m}^{-2} \mathrm{yr}^{-1}$ and the mean phytoplankton biomass $(0-15 \mathrm{~m})$ remained relatively stable at $2.5 \mathrm{~g} \mathrm{FW} \mathrm{m}^{-3}$ (Gammeter and Zimmermann, 2001).

The lake is usually monomictic, but holomixis is rather exceptional (Kutschke, 1966; Oern, 1980). In warm winters, or in such with poor wind activities, mixing depth reaches only 60 to $100 \mathrm{~m}$. Inverse stratification is observed only in cold winters mostly during a short period at the beginning of March. Complete ice cover occurs (statistically) once in every 25 years, the last one dating back to 1963 . From May until October a stable thermocline develops between 8 and $15 \mathrm{~m}$ depth, with maximum gradients of $3.5^{\circ} \mathrm{C} \mathrm{m}^{-1}$. Temperature in the epilimnion exceeds $20^{\circ} \mathrm{C}$ for usually 2 months and reaches maximum values of $25^{\circ} \mathrm{C}$ at the surface. The euphotic zone extends down to $10.0 \pm 2.5 \mathrm{~m}$ depth during summer stratification (April-September).

In the 10 to $12 \mathrm{~m}$ layer Planktothrix rubescens grows to very high densities (up to $10 \mathrm{mg} \mathrm{FW} \mathrm{1}^{-1}$ ) in late summer (Micheletti et al., 1998; influence on spectral light attenuation, see Schanz, 1986). Usually at the end of September the Planktothrix filaments are distributed within the whole epilimnion. P. rubescens accounts for more than $50 \%$ of the total phytoplankton biomass from September to March. The biomass reaches low values between end of May and mid of July (Walsby et al., 1998). Several other cyanobacterial genera appear regularly in early autumn: Aphanothece, Aphanocapsa, Microcystis and Aphanizomenon. Numerous Chlorophyta species occur, but they account for less than $10 \%$ of phytoplankton biomass. Typical autumn Chrysophyta species are Dinobryon and Fragilaria crotonensis. Cryptophyta (Cryptomonas, Rhodomonas) and Dinophyta (mainly Ceratium hirundinella) make up for the remaining $20 \%$ of total biomass. In winter diatoms and flagellates are frequent besides the dominating Planktothrix and in spring centric diatoms and cryptophytes (Rhodomonas) are regularly blooming (Bleiker and Schanz, 1989).

\section{Key parameters measured in summer 1999}

Figure 4 presents a summary of the two sampling days of 4 August and 8 September 1999. Temperature in the epilimnion reached maximum values of $24^{\circ} \mathrm{C}$ in August. By the time of the GAP Workshop, a stable thermocline had established 

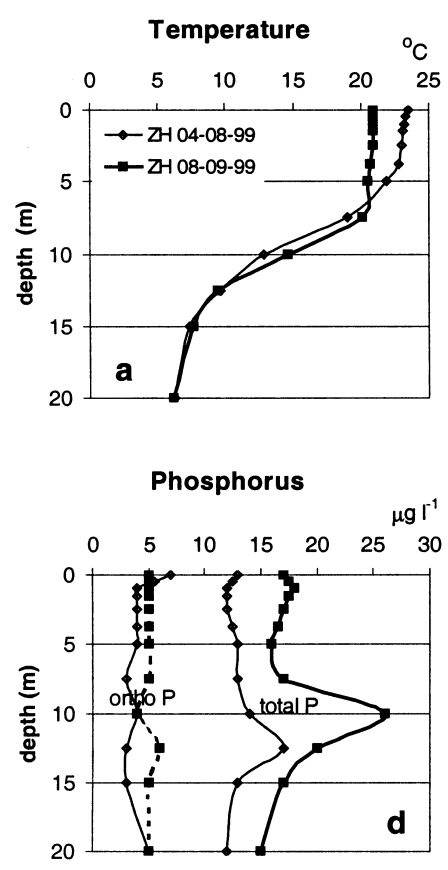

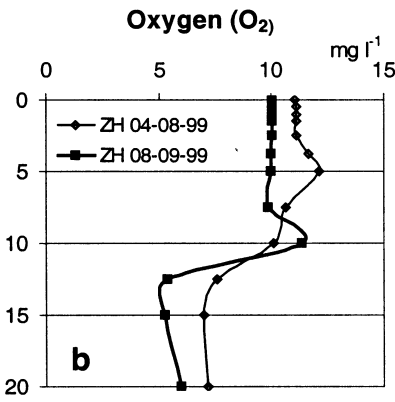

Nitrate $\left(\mathrm{NO}_{3}-\mathrm{N}\right)$



Phytoplankton in August


Total inorganic Carbon



Silicate $\left(\mathrm{SiO}_{2}\right)$

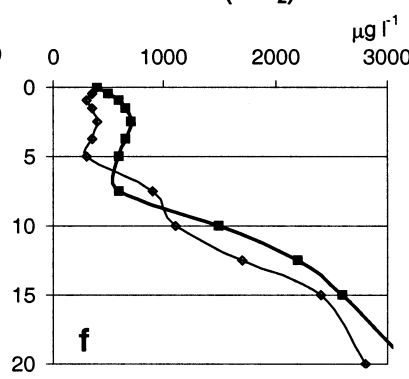

Phytoplankton in September



Figure 4. Lake Zürich, Thalwil, depth profiles of 4 August (diamonds) and 8 September (squares) 1999, for (a) temperature, (b) oxygen, (c) total dissolved inorganic carbon (DIC), (d) ortho-phosphate (SRP) and total-phosphorus $\left(\mathrm{P}_{\text {tot }}\right)$, (e) nitrate, (f) silicate, (g) PAR transparency in percent of incident radiation at the water surface, with inset $\left(\mathrm{g}_{1}\right) \log$ representation, $(\mathrm{h})$ phytoplankton biomass and Planktothrix rubescens on 4 August in $\mathrm{mg} \mathrm{FW}^{-1}(\mathrm{j})$

between 8 and $12 \mathrm{~m}$ (temperature difference $9{ }^{\circ} \mathrm{C}$, or $2.25^{\circ} \mathrm{C} \mathrm{m}^{-1}$ ). This resulted in a clear separation of epilimnion $(0-8 \mathrm{~m})$, metalimnion $(8-12 \mathrm{~m})$ and hypolimnion (Fig. 4a).

The phytoplankton community was dominated in early August by chrysophytes, followed by cyanophytes, diatoms and dinophytes. Thereafter, the cyanophytes increased their biomass drastically in the deep trophogenic layer (Figs. $4 \mathrm{~h}$ and $\mathrm{j}$ ) and dominated total phytoplankton biomass in late summer and fall, while the bio- 



Figure 4 (continued) (j) phytoplankton biomass and Planktothrix rubescens on 8 September in mg FW $1^{-1}$ (k) chlorophyll $a$, (l) photosynthetic C-assimilation, and (m) chlorophyll-specific Cassimilation (assimilation number, AN)

mass of chrysophytes and diatoms decreased considerably (Fig. 5), also in the upper epilimnion (Figs. $4 \mathrm{~h}$ and $\mathrm{j}$ ).

The epilimnetic nutrient concentrations do not appear to be limiting (Fig. 4 d-f):

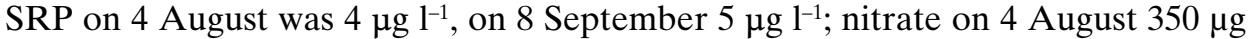

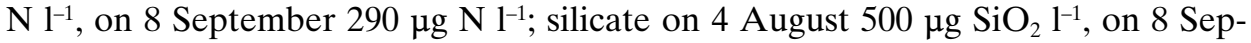
tember $575 \mu \mathrm{g} \mathrm{SiO}_{2} \mathrm{l}^{-1}$. However, chlorophyll $a$ concentrations were only moderate (6 $\mathrm{g} \mathrm{l}^{-1}$ in August, $2.5 \mu \mathrm{g} \mathrm{l}^{-1}$ in September) as were the phytoplankton fresh weights (3.2 $\mathrm{mg} \mathrm{l}^{-1}$ in August and $1.4 \mathrm{mg} \mathrm{l}^{-1}$ in September, see Fig. $4 \mathrm{~h}, \mathrm{j}$ ). Most of the biomass was concentrated in the metalimnion, at $10 \mathrm{~m}$ depth. This metalimnetic phytoplankton consists to about $80 \%$ of the filamentous cyanobacterium Planktothrix rubescens (Fig. $4 \mathrm{~h}, \mathrm{j}$ ). A peak at $10 \mathrm{~m}$ depth in oxygen (Fig. $4 \mathrm{~b}$ ) and total phosphorus (Fig. $4 \mathrm{~d}$ ) underpin the significance of this metalimnetic production. Planktothrix rubescens is avoided by most zooplankton species, probably because of its high microcystin content (Kurmayer and Jüttner, 1999).

Euphotic depth (1\% of surface PAR) was $9.7 \mathrm{~m}$ on 4 August and $10.7 \mathrm{~m}$ on 8 September 1999 . The attenuation coefficient $\left(K_{\mathrm{d}}\right)$ in the epilimnion was $0.466 \mathrm{~m}^{-1}$ on 4 August and $0.462 \mathrm{~m}^{-1}$ on 8 September. In the Planktothrix layer in September $K_{\mathrm{d}}$ was much higher $\left(0.967 \mathrm{~m}^{-1}\right.$ between 10 and $\left.12.5 \mathrm{~m}\right)$.

The PP was only moderate in the 0 to $7.5 \mathrm{~m}$ layer showing values between 5 and $13 \mathrm{mg} \mathrm{C} \mathrm{m}^{-3} \mathrm{~h}^{-1}$. The PP of Planktothrix filaments at $10 \mathrm{~m}$ depth was quite high dur-

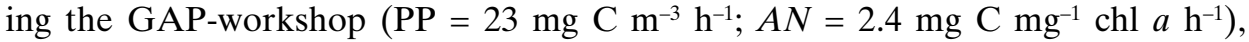






Figure 5. Phytoplankton community structure in the trophogenic layer $(0-20 \mathrm{~m})$ of Lake Zürich, Thalwil of 4 August, 8 September, and 6 October, and Zollikon of 18 August and 22 September 1999; biomass in $\mathrm{g} \mathrm{FW} \mathrm{m}^{-2}$

although the mean light intensity during the exposition period was only $5 \mu \mathrm{mol}$ $\mathrm{m}^{-2} \mathrm{~s}^{-1}$. On 4 August, the majority of the filaments were too deep in the metalimnion $(12.5 \mathrm{~m})$ to support a considerable PP, in spite of the high chlorophyll $a$ content of $13 \mathrm{mg} \mathrm{m}^{-3}(\mathrm{PP}=2 ; A N=0.2)$. In the upper $5 \mathrm{~m}$ the main contribution to the $\mathrm{PP}$ at that day was caused by Dinobryon, Peridinium and centric diatoms (see also Fig. 5). On 8 September the scarce phytoplankton in the epilimnion was more active in terms of assimilation per chlorophyll $a(A N=2.85$, mean of 0 to $5 \mathrm{~m}$ depth layer $)$ than on 4 August $(A N=2.2)$, probably due to the presence of Rhodomonas and Cryptomonas species.

\section{Lake Cadagno}

Lake Cadagno is an alpine meromictic lake in the Piora Valley at $1921 \mathrm{~m}$ a.s.l. in the southern part of Switzerland. The $21 \mathrm{~m}$ deep lake basin was formed by glacial erosion and dammed by a glacial moraine. Today it serves as one of the reservoirs for a hydroelectric power plant in Piotta and thus undergoes each winter water level fluctuations of $3 \mathrm{~m}$. In summer the lake frequently receives loads of organic matter (cattle manure, waste products of cheese manufacture) which increases the nutrient level leading to a trophy shift during the summer months (Schanz and Stalder, 1998). This is reflected by the exceptionally high concentrations of dissolved organic carbon (DOC, $1.5-2 \mathrm{mg} \mathrm{Cl}^{-1}$ ) for an alpine lake at this altitude.

The mixolimnion of Lake Cadagno is fed by electrolyte-poor surface water. It spans down to 11-12 m water depth. The monimolimnion consists of salt-rich water (mainly sulfate, carbonate, calcium and magnesium) which is constantly supplied by subaquatic springs. The water masses of the lake are stabilized by the large density 

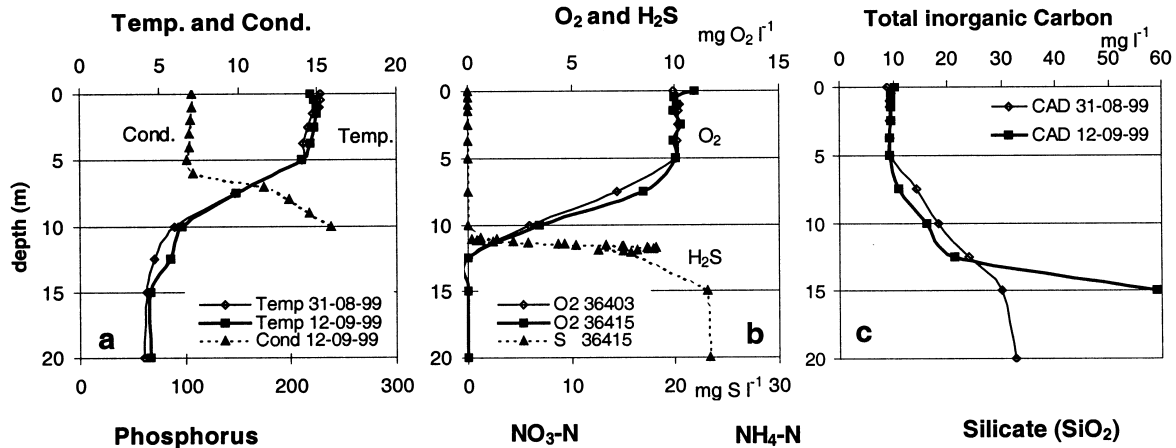

Phosphorus

$\mathrm{NO}_{3}-\mathrm{N}$

$\mathrm{NH}_{4}-\mathrm{N}$
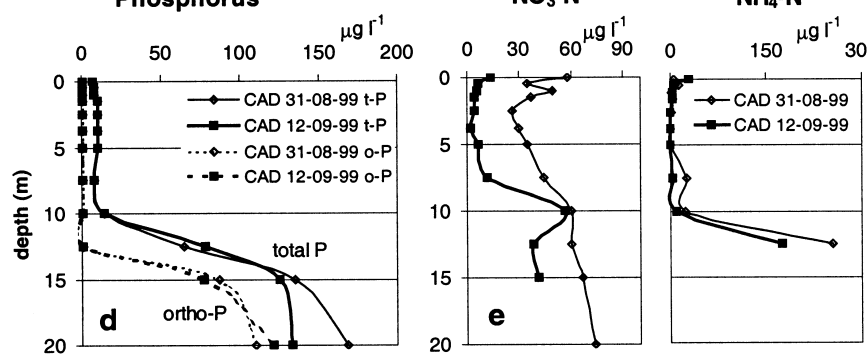

Silicate $\left(\mathrm{SiO}_{2}\right)$
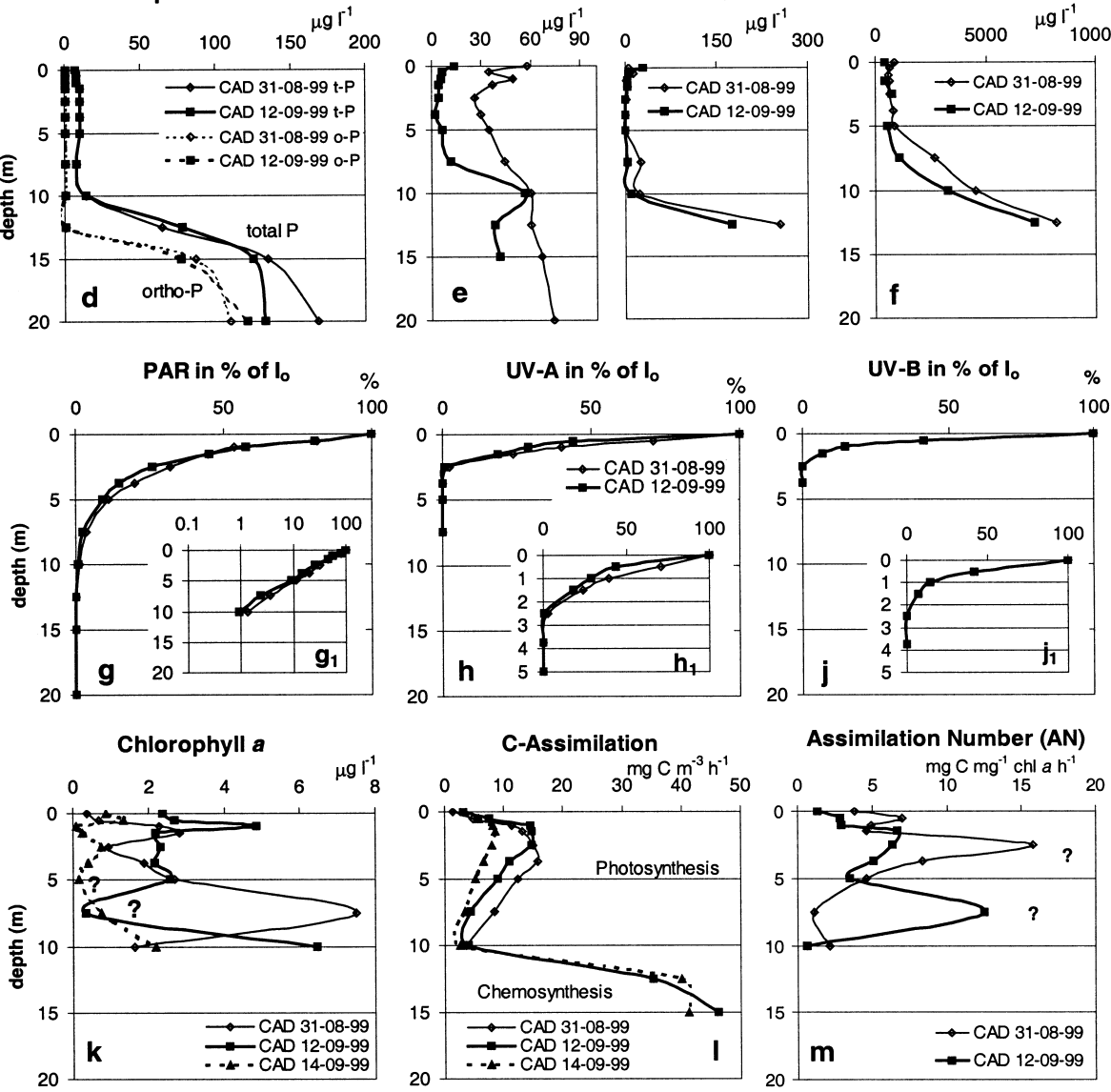

Figure 6. Lake Cadagno, center of the lake, depth profiles of 31 August (diamonds) and 12 September (squares) 1999, for (a) temperature and conductivity, (b) oxygen and sulfide, (c) total dissolved inorganic carbon (DIC), (d) ortho-phosphate (SRP) and total-phosphorus $\left(P_{\text {tot }}\right),($ e) nitrate and ammonia, (f) silicate, (g) PAR transparency in percent of incident radiation at the water surface, with inset $\left(\mathrm{g}_{1}\right) \log$ representation, (h) UV-A transparency with inset $\left(\mathrm{h}_{1}\right)$ zoom of the uppermost five meters, (j) UV-B transparency with inset $\left(\mathrm{j}_{1}\right)$ zoom, (k) chlorophyll $a$ (uncorrected), (l) photosynthetic $\mathrm{C}$-assimilation, and $(\mathrm{m}$ ) chlorophyll-specific $\mathrm{C}$-assimilation (assimilation number, AN) 
Table 4. Lake Cadagno, key parameters for primary production in summer 1999

\begin{tabular}{|c|c|c|c|c|c|c|c|}
\hline Date & $\begin{array}{l}\text { Surface } \\
\text { PAR I }_{0} \\
{[\mu \mathrm{mol}} \\
\left.\mathrm{m}^{-2} \mathrm{~s}^{-1}\right]\end{array}$ & $\begin{array}{l}10 \% \text { of } \\
\text { surface } \\
\text { PAR, } \\
\text { depth [m] }\end{array}$ & $\begin{array}{l}\text { Phyto- } \\
\text { plankton } \\
0-10 \mathrm{~m} \\
{\left[\mathrm{~g} \mathrm{FW} \mathrm{m}^{-2}\right]}\end{array}$ & $\begin{array}{l}\text { Chl } a \\
0-10 \mathrm{~m} \\
{\left[\mathrm{mg} \mathrm{m}^{-2}\right]}\end{array}$ & $\begin{array}{l}\mathrm{Chl} b \\
0-10 \mathrm{~m} \\
{\left[\mathrm{mg} \mathrm{m}^{-2}\right]}\end{array}$ & $\begin{array}{l}\text { APP } \\
0-10 \mathrm{~m} \\
{\left[\mathrm{mg} \mathrm{C} \mathrm{m}^{-2}\right.} \\
\left.\mathrm{h}^{-1}\right]\end{array}$ & $\begin{array}{l}\text { AN } \\
\text { ave. } 0-5 \mathrm{~m} \\
{[\mathrm{mg} \mathrm{C}(\mathrm{mg}} \\
\left.\text { chl } a)^{-1} \mathrm{~h}^{-1}\right]\end{array}$ \\
\hline $31-08-9$ & 1140 & 5.4 & n.d. & 33.0 & & 102.2 & 7.03 \\
\hline $12-09-99$ & 833 & 4.9 & 43 & 24.9 & 4. & 86.1 & $4.11 \pm 1.98$ \\
\hline 14-09-99 & 664 & & & 7.4 & 2.9 & 52.4 & $26.4 \pm 28.6$ \\
\hline
\end{tabular}

differences between the mixolimnic and the monimolimnic water. The monimolimnion of the lake is constantly anoxic and sulfide is accumulated up to $23 \mathrm{mg}$ $\mathrm{l}^{-1}$ (see e.g. Lehmann and Bachofen, 1999, and Fig. 6b), thus the pycnocline parallels a redoxcline and a chemocline, a depth where dense populations of phototrophic bacteria are naturally enriched. Fischer et al. (1996) studied the light environment and the synthesis of bacteriochlorophyll by populations of Chromatium okenii. Growth and production of the bacterial layer was described by Schanz et al. (1998). The peculiar phenomenon of crenogenic meromixis has attracted scientists already early in the $20^{\text {th }}$ century and is described in detail by Del Don et al. (2001).

Most of the following generalizations are based on short term investigations mainly during the summer seasons of the past two decades (see also Peduzzi et al., 1998). Secchi depths, measured in July, averaged in the past decade $6.8 \pm$ $0.6 \mathrm{~m}$ (Tonolla, unpublished results). Epilimnetic nutrient concentrations (in the uppermost $10 \mathrm{~m}$ ) are low during summer. While $\mathrm{PO}_{4}-\mathrm{P}$ approaches detection limits $\left(<1 \mu \mathrm{g} \mathrm{Pl}^{-1}\right), \mathrm{NO}_{3}-\mathrm{N}$ is below $50 \mu \mathrm{g} \mathrm{N} \mathrm{l}^{-1}$ and DIC ranges around $10 \mathrm{mg} \mathrm{l}^{-1}$. The concentrations of these nutrients increase with depth in the anoxic monimolimnion to near bottom values of approximately $100 \mu \mathrm{gO}_{4}-\mathrm{P} \mathrm{l}^{-1}, 400 \mu \mathrm{g} \mathrm{NH}_{4}-\mathrm{N}^{-1}$ and $20 \mathrm{mg}$ DIC 1-1 (Del Don, 1986; Friedl, 1987; Tonolla et al., 1998 and 1999).

The epilimnetic phytoplankton community $(0-10 \mathrm{~m})$ starts out in early summer with a relatively even distribution of centric and pennate diatoms, green algae (mainly Scenedesmus and Dictyosphaerium), cryptophytes and dinophytes. During summer pennate and centric diatoms (Fragilaria, Stephanodiscus, Cyclotella sp.) take over. In late summer green algae (mainly Sphaerocystis and later Oocystis) dominate (Schanz and Stalder, 1998). Chlorophyll $a$ concentrations vary considerably, e. g. in summer 1988 between $26 \mathrm{mg} \mathrm{m}^{-2}$ in late July and $4 \mathrm{mg} \mathrm{m}^{-2}$ in early September, or in summer 1986 between 18 and $65 \mathrm{mg} \mathrm{m}^{-2}$ (Schanz and Friedl, 1993).

The PP from July to September 1986 (Friedl, 1987) varied between 23 and $79 \mathrm{mg}$ $\mathrm{C} \mathrm{m}^{-2} \mathrm{~h}^{-1}$ in the layer from the surface down to $9.5 \mathrm{~m}$ depth which is the zone dominated by aerobic phytoplankton organisms. The euphotic zone ( $>$ depth of $1 \%$ surface PAR) remained very stable during this period $(11.6 \pm 0.3 \mathrm{~m})$. The low intensity of light below $9.5 \mathrm{~m}$ depth is efficiently used by phototrophic bacteria in anoxygenic photosynthesis with sulfide as electron donor (Schanz et al., 1998). According to the data of Friedl (1987) bacterial production below $10 \mathrm{~m}$ depth was in the average $50 \%$ of the 0 to $9.5 \mathrm{~m}$ phytoplankton production (range $12-97 \%$ ). $A N_{\max }$ (in the $0-5 \mathrm{~m}$ depth layer) was between 1.8 and $6.7 \mathrm{mg} \mathrm{C}(\mathrm{mg} \mathrm{chl} a)^{-1} \mathrm{~h}^{-1}$, exceeding $5 \mathrm{mg} \mathrm{C}(\mathrm{mg} \operatorname{chl} a)^{-1} \mathrm{~h}^{-1}$ only twice. The near surface $A N$ ( 0 to $2 \mathrm{~m}$ layer), calculated 
in August 1997 (Pasini, 1999; Pasini and Schanz, 1998), were in the range of 1.3 to $6.5 \mathrm{mg} \mathrm{C}(\mathrm{mg} \operatorname{chl} a)^{-1} \mathrm{~h}^{-1}$ with a mean of $4.3 \mathrm{mg} \mathrm{C}(\mathrm{mg} \mathrm{chl} a)^{-1} \mathrm{~h}^{-1}$. Therefore, no statistical significant difference between the datasets of 1986 and 1997 is expected.

\section{Key parameters for primary production in summer 1999}

Figure 6 presents a summary of the two sampling days on 31 August and 12 September 1999.

The vertical temperature profile remained stable during the first two weeks in September. The lake had developed a pronounced thermocline between 5 and $12 \mathrm{~m}$ depth with a temperature difference of $10^{\circ} \mathrm{C}$ (gradient $\left.1.4^{\circ} \mathrm{C} \mathrm{m}^{-1}\right)$. The thermic stability was additionally strengthened by the density gradient which was most prominent between 5 and $10 \mathrm{~m}$ depth, as deduced from the conductivity data (increase from $100 \mu \mathrm{S} \mathrm{cm}^{-1}$ at $5 \mathrm{~m}$ water depth to $250 \mu \mathrm{S} \mathrm{cm}^{-1}$ at $10 \mathrm{~m}$ water depth). Vertical mixing above the thermocline caused homogeneous concentrations of all dissolved compounds in the mixolimnion, while in the meta- and hypolimnion steep gradients had established. This is deduced from the oxygen curve showing a sharp decline from 10 to $0 \mathrm{O}_{2} \mathrm{mg} \mathrm{l}^{-1}$ between 5 and $12 \mathrm{~m}$ depth. SRP was $0.5 \mu \mathrm{g} \mathrm{P} \mathrm{l}^{-1}$ throughout the euphotic zone (0-5 m depth). Dissolved nitrate $\left(<50 \mu \mathrm{g} \mathrm{N}^{-1}\right)$ was very low compared to Lake Zürich and Lake Lucerne, and decreased in the euphotic zone within two weeks by $66 \%$ or $269 \mathrm{mg} \mathrm{N} \mathrm{m}^{-2}$. This resulted in an average nitrate concentration on 12 September of $13.4 \mu \mathrm{g} \mathrm{NO}_{3}-\mathrm{N}^{-1}$. Such a loss is easily explained by $\mathrm{N}$-consumption during growth at an average areal daily PP of $200 \mathrm{mg} \mathrm{C} \mathrm{m}^{-2} \mathrm{~d}^{-1}$. DIC concentration remained stable in the euphotic zone during the two weeks period, showing a relatively low value of about $10 \mathrm{mg} \mathrm{Cl}^{-1}$ as a consequence of the incoming soft water from the crystalline rock region of the catchment area. The DIC concentrations increased considerably towards the lake bottom up to $30 \mathrm{mg} \mathrm{Cl}^{-1}$ on 31 August and up to $58 \mathrm{mg} \mathrm{l}^{-1}$ on 12 September.

The euphotic depth (1\% of surface PAR) was $10 \mathrm{~m}$ and thus covered the epiand metalimnion down to the layer of photosynthetic sulfur bacteria (Schanz et al., 1998). $10 \%$ of the surface radiation were measured on 12 September for PAR at a depth of $4.9 \mathrm{~m}\left(K_{\mathrm{d}, \mathrm{PAR}}=0.47 \mathrm{~m}^{-1}\right)$, for UV-A at $2.0 \mathrm{~m}\left(K_{\mathrm{d}, \mathrm{UV}-\mathrm{A}}=1.08 \mathrm{~m}^{-1}\right)$, and for UV$\mathrm{B}$ at $1.3 \mathrm{~m}\left(K_{\mathrm{d}, \mathrm{UV}-\mathrm{B}}=1.70 \mathrm{~m}^{-1}\right)$.

The vertical distribution of PP (Fig. 61), measured on 31 August, 12 and 14 September, was of similar shape in all three depth profiles: a low production close to the surface, a distinct production maximum located at a depth of $1.5-3.75 \mathrm{~m}$, and a production minimum at $10 \mathrm{~m}$ (depth of $1 \%$ surface light intensity = compensation depth for oxygenic photosynthesis). Below $10 \mathrm{~m}$ very high values of phototrophic (caused by the sulfur bacteria Amoebobacter cf. purpureus and Chromatium okenii) and chemotrophic C-assimilation were observed (for details see Camacho et al., 2001).

While chlorophyll concentrations (Fig. 6k) showed large variations with depth on all sampling days, the PP profiles were smooth. As a consequence, the assimilation numbers $(A N)$, calculated from $\mathrm{C}$-assimilation and chlorophyll, varied accordingly and yielded in some depths incorrect values (Fig. $6 \mathrm{~m}$ ).

The phytoplankton community in early September is described in detail by Camacho et al. (2001). The upper water body of the euphotic zone was dominated 
by the green algae Echinocoleum elegans and Elakatothrix sp. and the diatom Cyclotella radiosa. Furthermore various picoplankton were present in smaller concentrations. Total phytoplankton fresh weight in the euphotic zone from $0-10 \mathrm{~m}$ depth was $43 \mathrm{~g} \mathrm{FW} \mathrm{m}^{-2}$ (calculated from data obtained by Camacho et al., 2001). Immediately below the euphotic zone (at $10.8-11.2 \mathrm{~m}$ ) a dense population of diatoms, mainly Fragilaria capucina and Cyclotella comensis, peaked in the oxic water at the upper edge of the chemocline and added considerably to the total phytoplankton fresh weight (from 0-12 $\mathrm{m}$ depth: $56 \mathrm{~g} \mathrm{FW} \mathrm{m}^{-2}$ ).

Zooplankton species, mainly Daphnia longispina, Acanthodiaptomus denticornis and Bosmina longirostris among the crustaceans, as well as Conochilus sp. and, less abundant, Asplanchna priodonta among the rotifers, were observed.

\section{Comparison of primary production properties in the Lakes Lucerne, Zürich and Cadagno}

In August (Table 5a), all three lakes showed at nearly equal surface insolation ( $I_{0}$, $1140-1273 \mu \mathrm{mol} \mathrm{m}^{-2} \mathrm{~s}^{-1}$ ) similar areal primary production (APP, $90-105 \mathrm{mg} \mathrm{C} \mathrm{m}^{-2}$ $\mathrm{h}^{-1}$ ) despite different chlorophyll standing crops. Due to a higher water transparency the euphotic depth and thus primary production (PP) extended in Lake Lucerne into deeper zones than in Lake Zürich (Table 5). The lower areal chlorophyll standing crop in Lake Lucerne yielded a higher chlorophyll-specific areal production rate (AAN) and thus an APP similar to Lake Zürich.

AAN in the alpine Lake Cadagno were considerably higher than in the two lowland lakes. In September, AAN in all three lakes were higher than in August, as had been observed in former years.

It is notable that in Lake Zürich the APP was higher in September (124.5 mg C $\left.\mathrm{m}^{-2} \mathrm{~h}^{-1}\right)$ than in August $\left(105 \mathrm{mg} \mathrm{C} \mathrm{m}^{-2} \mathrm{~h}^{-1}\right)$ in spite of a smaller chlorophyll standing crop (74.5 versus $120 \mathrm{mg} \mathrm{m}^{-2}$ ), and nearly equal $I_{0}$ and $K_{\mathrm{d}}$. Planktothrix rubescens must be responsible for the apparent discrepancy, as it is able to achieve high assimilation rates at very low light intensities (see Fig. 41).

Table 5. Comparison of areal primary production in Lakes Lucerne, Zürich and Cadagno

\begin{tabular}{lcclcc}
\hline Lake /Date & $\begin{array}{l}\text { Chl } a \\
{\left[\mathrm{mg} \mathrm{m}^{-2}\right]}\end{array}$ & $\begin{array}{l}\text { APP } \\
{\left[\mathrm{mg} \mathrm{C} \mathrm{m}^{-2} \mathrm{~h}^{-1}\right]}\end{array}$ & $\begin{array}{l}\text { AAN } \\
{[\mathrm{mg} \mathrm{C}(\mathrm{mg}} \\
\left.\mathrm{chl} a)^{-1} \mathrm{~h}^{-1}\right]\end{array}$ & $\begin{array}{l}\text { Euphotic zone } \\
{[\mathrm{m}]}\end{array}$ & $\begin{array}{l}\text { Surface PAR } \\
{\left[\mu \mathrm{mol} \mathrm{m}^{-2} \mathrm{~s}^{-1}\right.}\end{array}$ \\
\hline $\begin{array}{l}\text { a) } \text { in August } \\
\text { Lucerne/25.8.99 }\end{array}$ & 78.7 & 90.2 & 1.15 & 17.7 & 1273 \\
Zürich/4.8.99 & 120.8 & 105.2 & 0.87 & 9.8 & 1251 \\
Cadagno/31.8.99 & 33.0 & 102.2 & 3.10 & 10.4 & 1140 \\
b) in September & & & & & \\
Lucerne/13.9.99 & 34.5 & 52.1 & 1.51 & 15.1 & 1010 \\
Zürich/8.9.99 & 74.5 & 124.5 & 1.67 & 10.9 & 1245 \\
Cadagno/12.9.99 & 24.8 & 86.1 & 3.47 & 9.9 & 833 \\
Cadagno/14.9.99 & 14.2 & 52.4 & 3.62 & & 664 \\
\hline
\end{tabular}


Plots of $A N$ versus ambient light intensity $\left(I_{z}\right)$ in the in situ depth profiles of the three lakes (Fig. 7) showed in September an (inhibitory) decrease in $A N$ at $I_{\mathrm{z}}>$ $500 \mu \mathrm{mol} \mathrm{m}^{-2} \mathrm{~s}^{-1}$. $A N$ in Lake Cadagno samples (outliers in Fig. $6 \mathrm{~m}$ were corrected with the help of simultaneous in situ incubations with UV-screens) were considerably depressed at even lower intensities $\left(<300 \mu \mathrm{mol} \mathrm{m} \mathrm{m}^{-2} \mathrm{~s}^{-1}\right)$ on both dates of 31 August and 12 September. In August no inhibition of $A N$ occurred in the Lakes Lucerne and Zürich. Additional simultaneous incubations in bottles covered with UV absorbing material revealed, however, a distinct inhibitory effect on the PP by ambient UV, not only in September but also in August (Fig. 8). The PP profile in Lake Zürich of 4 August can be seen as a 'no UV experiment', since the bottles used for incubation absorbed most of the UV radiation ( $93 \%$ absorption at $325 \mathrm{~nm}, 40 \%$ at $350 \mathrm{~nm}$ ). This may explain the missing inhibition of photosynthesis in the uppermost meter in August, compared to the September profile, when Duran glass bottles (38\% absorption at $325 \mathrm{~nm}, 5 \%$ at $350 \mathrm{~nm}$ ) were used.

Physiological parameters of primary production, such as calculated $P_{\mathrm{S}}^{\mathrm{B}}, \alpha$, and $\beta$ could not be calculated with high accuracy because of a considerable scatter in the data, but sufficient information was obtained to categorize the three lakes. Figure 9 shows some rough estimates calculated by different approaches: a) estimates from selected measured data (open bars) and b) curve-fitting (shaded bars) according to Platt et al. (1980) as described in "Materials and Methods".

These calculations show that the initial slope $\alpha$ tends to rise from August to September in all three lakes, being the lowest in Lake Lucerne with the deepest euphotic zone. The considerable increase of the coefficient $\alpha$ in Lake Zürich from August to September can be explained with the rôle of Planktothrix which shows an efficient utilization of light at low light intensities. The coefficient $\beta$ (characterizing the slope of inhibition) is highest in Lake Cadagno, followed by Lake Lucerne and Lake Zürich. The hypothetical parameter $P_{\mathrm{S}}^{\mathrm{B}}$ (the calculated maximum photosynthetic output the algae could sustain if there were no photoinhibition), is highly dependent on the shape of the calculated $P$ versus $I$ curve (especially on $\beta$ ) and therefore affected by the data scatter in the upper epilimnion. If inhibition is mainly caused by UV radiation and less by high light intensities, as Figure 8 suggests for most cases (see also Neale et al., 2001 a, this issue), calculated $P_{\mathrm{S}}^{\mathrm{B}}$ should be only slightly higher than or equal to the measured $A N_{\max }$ as observed in samples covered with UV fil-

Lake Lucerne

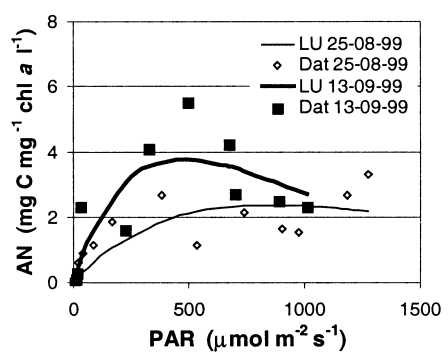

Lake Zürich

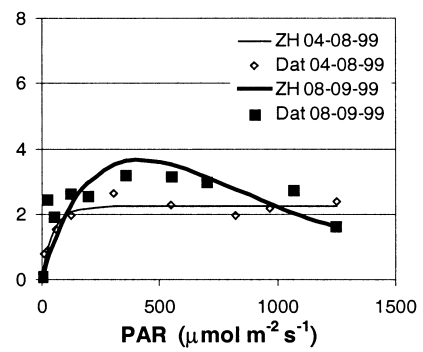

Lake Cadagno



Figure 7. $P$ versus $I$ curves of the Lakes Lucerne, Zürich and Cadagno, in August and September 1999 , calculated with equation $P^{\mathrm{B}}=P B S\left(1-e^{-\alpha / P B S}\right) e^{-\beta / P B S}$ 

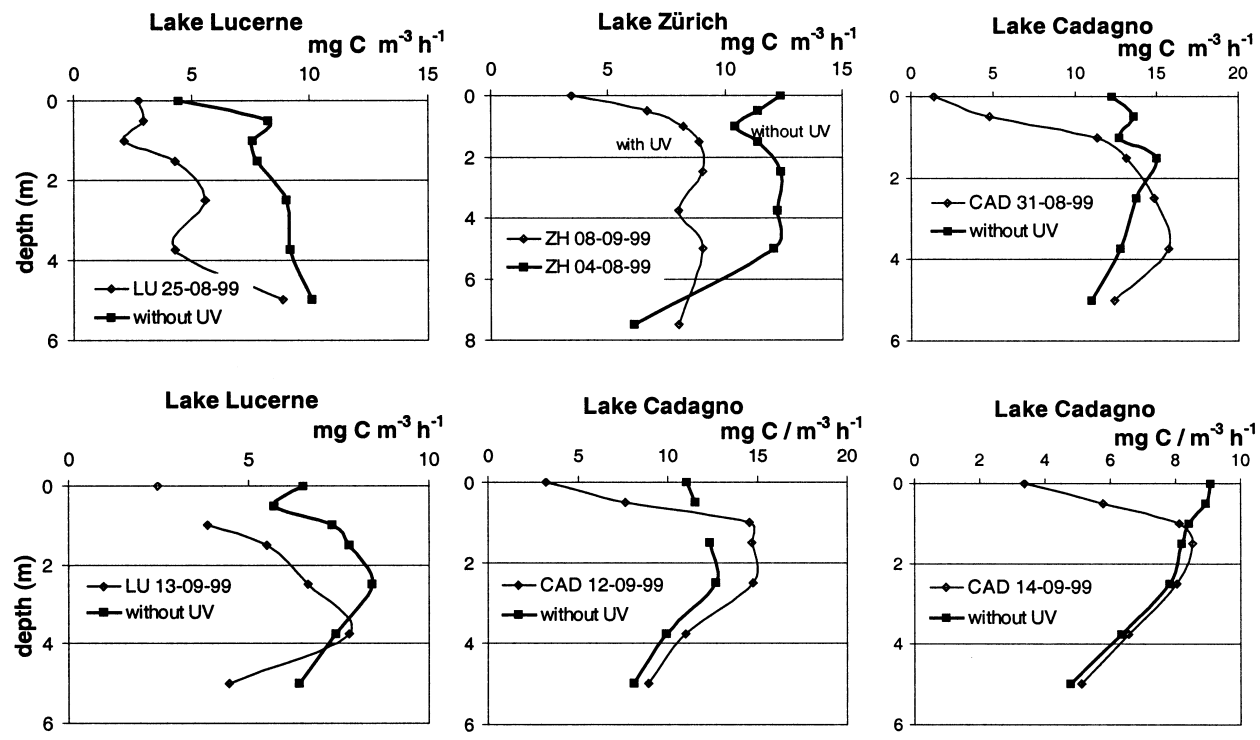

Figure 8. Depth profiles of photosynthetic in situ C-assimilation. In the Lakes Lucerne and Cadagno bottles incubated with and without exposure to UV radiation using Duran glass and UVfilters. Lake Zürich samples incubated in bottles of two different glass qualities (incubation on 4 August with plain glass bottles being more opaque to UV than the Duran bottles used on 8 September)

ters or in samples exposed to low UV radiation. Calculated $P_{\mathrm{S}}^{\mathrm{B}}$ exceed in most cases measured $A N_{\max }$ in the Lakes Cadagno and Lucerne, especially when determined by simultaneous calibration of all three coefficients. For calculated $P_{\mathrm{S}}^{\mathrm{B}}$ higher than $10\left[\mathrm{mg} \mathrm{C}(\mathrm{mg} \mathrm{chl} a)^{-1} \mathrm{~h}^{-1}\right.$ ] we hesitate to quantify the influence of the solar radiation on the observed inhibition of C-assimilation. In Lake Zürich, however, where little inhibition was observed, calculated $P_{\mathrm{S}}^{\mathrm{B}}$ and measured $A N_{\max }$ correspond rather well.

In conclusion, the biological and physiological properties of phytoplankton in the three lakes during the GAP workshop in mid-September 1999 can be categorized as follows:

Lake Lucerne: A relatively low phytoplankton biomass (app. $7 \mathrm{~g} \mathrm{FW} \mathrm{m}^{-2}$ ), with a high chlorophyll content ( $35 \mathrm{mg} \mathrm{chl} a \mathrm{~m}^{-2}$ ), originating from mainly chrysophytes and diatoms, spread through a stratified euphotic zone of $15 \mathrm{~m}$ extension and increased with depth. The phytoplankton population in this oligotrophic lake is phosphate limited and yields a moderate APP of the same size as the mesotrophic Lake Cadagno. $A N$ at low light intensities is rather low (flat initial slope $\alpha$ ), while $A N_{\text {max }}$ and $\beta$ are moderate, when compared to the other two lakes.

Lake Zürich: A relatively high phytoplankton biomass (app. $42 \mathrm{~g} \mathrm{FW} \mathrm{m}^{-2}$ ) combined with a low chlorophyll content (66 $\mathrm{mg}$ chl $a \mathrm{~m}^{-2}$ ) originating from cyanophytes, chrysophytes, diatoms and dinophytes peaks in the lowest part of the 

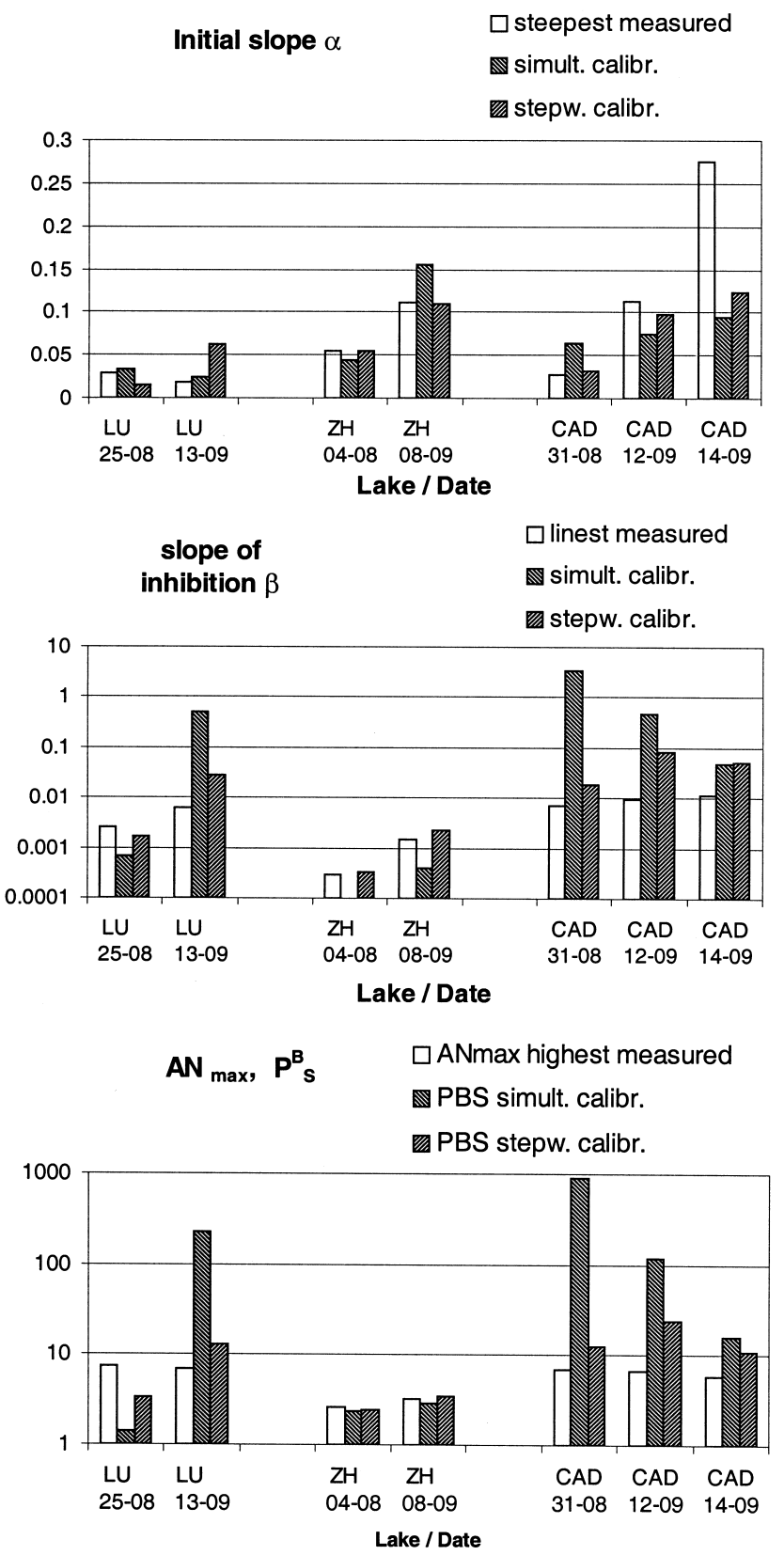

Figure 9. Characteristic factors of $P$ versus $I$ curves: $A N_{\max }, P_{\mathrm{S}}^{\mathrm{B}}, \alpha$, and $\beta$, determined in the Lakes Lucerne, Zürich and Cadagno in August and September 1999. The factors (coefficients) were determined (i) from measured data ( $\alpha$ : steepest slope measured, $\beta$ : straight line calculated by using the least squares method, $A N_{\text {max }}$ : highest value of AN in the depth profile), (ii) by curve fitting with equation $P^{\mathrm{B}}=P B S\left(1-e^{-\alpha / P B S}\right) e^{-\beta I / P B S}$ (simultaneous and stepwise calibration of the coefficients). For further explanations see text 
euphotic zone (dominated by Cyanobacteria) of $11 \mathrm{~m}$ extension. APP is rather high compared to the other two lakes. $A N$ at low light intensities is high, due to the Planktothrix layer. $A N_{\max }$ and $\beta$ are low.

Lake Cadagno: A relatively high phytoplankton biomass (app. $43 \mathrm{~g} \mathrm{FW} \mathrm{m}^{-2}$ ) combined with a rather low chlorophyll content, (app 7-20 $\mathrm{mg} \operatorname{chl} a \mathrm{~m}^{-2}$ ) is dominated by the chlorophyte Echinocoleum elegans. It spreads through a stratified euphotic zone of about $10 \mathrm{~m}$ extension. APP is moderate. The vertical distribution of photosynthetic C-assimilation peaks at $1-3 \mathrm{~m}$ depth and again, caused by the phototrophic sulfur bacteria Amoebobacter cf. purpureus and Chromatium okenii, at 11-12 m. High rates of dark C-assimilation by chemolithotrophic bacteria are observed in the chemocline (Camacho et al., 2001). $A N$ at low light intensities is rather high, due to the Amoebobacter-Chromatium layer. $A N_{\max }$ and $\beta$ are high. The high inhibition coefficient below the water surface of this alpine lake is mainly caused by the high UV-intensity at this altitude compared to the two lowland lakes.

\section{ACKNOWLEDGEMENTS}

This study was carried out for the $7^{\text {h }}$ International GAP Workshop, held on 9-17 Sept. 1999 in Zürich, Switzerland, and supported by the Swiss National Science Foundation (SNF), the Swiss Academies of Natural and Technical Sciences (SANW and SATW), the Swiss Society of Hydrology and Limnology (SGHL), by EAWAG, Zürich Water Supply and the University of Zürich, as well as by Hoffmann-La Roche, Lonza, Novartis, Canberra Packard S.A, Millipore AG and Faust Laborbedarf AG.

We are especially indebted to the numerous technical assistants and Ph.D. students of EAWAG, Zürich Water Supply and the University of Zürich, who volunteered in the field and in the laboratory before, during and after the GAP Workshop.

\section{REFERENCES}

APHA 1989, Standard methods for the examination of water and wastewater, American Public Health Association, Washington.

Bleiker, W. and F. Schanz, 1989. Influence of environmental factors on the phytoplankton spring bloom in Lake Zurich. Aquat. Sci. 51: 47-58.

Bloesch, J., P. Bossard, H. Bührer, H.-R. Bürgi and R. Müller, 1995. Lake oligotrophication due to external phosphorus load reduction in Swiss Lakes. Proceedings $6^{\mathrm{h}}$ internat. Conf. on the Conservation and Management of Lakes, Vol 2, Kasumigaura.

Bühlmann, B., P. Bossard, and U. Uehlinger, 1987. The influence of longwave ultraviolet radiation (u.v.-A) on the photosynthetic activity $\left({ }^{14} \mathrm{C}\right.$-assimilation) of phytoplankton. J. Plankton Res. 9: 935-943.

Bührer, H. and H. Ambühl, 1996: Der Vierwaldstättersee 1961-1992. Eine Dokumentation. Schriftenreihe EAWAG Nr. 10 (in German).

Bührer, H. and H. Ambühl, 2001. Lake Lucerne, Switzerland, a Long Term Study of 1961 - 1992. Aquat. Sci. 63/4, in press.

Bürgi, H.R., C. Heller, S. Gaebel, N. Mookerji and J.V. Ward, 1999. Strength of coupling between phyto- and zooplankton in Lake Lucerne (Switzerland) during phosphorus abatement subsequent to a weak eutrophication. J. Plankton Res. 21: 485-507.

Bürgi, H.R., P. Weber and H. Bachmann, 1985. Seasonal variations in the trophic structure of phyto- and zooplankton communities in lakes in different trophic states. Schweiz. Z. Hydrol. (now Aquatic Sciences) 47: 197-224. 
Camacho, A., J. Erez, A. Chicote, M. Florín, M.M. Squires, C. Lehmann and R. Bachofen, 2001. Microbial microstratification, inorganic carbon photoassimilation and dark carbon fixation at the chemocline of the meromictic Lake Cadagno (Switzerland) and its relevance to the food web. Aquat. Sci. 63: 91-106.

Carpenter, J.H., 1965. The accuracy of the Winkler method for dissolved oxygen analysis. Limnol. Oceanogr. 10: 135-140.

Del Don, C., K.W. Hanselmann, R. Peduzzi and R. Bachofen, 2001. The meromictic alpine Lake Cadagno: Orographical and biogeochemical description. Aquat. Sci. 63: 70-90.

Del Don, C., 1986. L'azione degli zolfobatteri fotosintetici nella zona di transizione ossidoreduzione del Lago meromitico di Cadagno: reciclaccio delle sostanze nutrienti e conseguenze sull'ecosistema del lago. Diploma thesis, University of Zürich and Istituto cantonale batteriosierologico, Lugano.

DEV, 1972-1989. Deutsche Einheitsverfahren zur Wasser-, Abwasser- und Schlammentwertung,. Hrsg.: Fachgruppe Wasserchemie in der Gesellschaft Deutscher Chemiker in Gemeinschaft mit dem Normenausschuss Wasserwesen (NAW) und dem Deutschen Institut für Normen (DIN), VCH Verlagsgesellschaft, Weinheim.

DEW, 1996. Deutsche Einheitsverfahren zur Wasseruntersuchung, Bd. II, VCH Weinheim, New York, Basel.

Fischer, C., M. Wiggli, F. Schanz, K. Hanselmann and R. Bachofen, 1996. Light environment and synthesis of bacteriochlorophyll by populations of Chromatium okenii under natural environmental conditions. FEMS Microbiol. Ecol. 21: 1-9.

Friedl, C., 1987. Ursachen von zeitlichen Veränderungen des Tiefenprofils der PhotosyntheseEffizienz im meromiktischen Cadagno-See. Diplomarbeit, Universität Zürich.

Gächter, R. and A. Mares, 1979. Comments on the acidification and bubbling methods for determining phytoplankton production. Oikos 33: 69-73.

Gammeter, S., R. Forster and U. Zimmermann, 1997. Limnologische Untersuchung des Zürichsees 1972-1996. Report by Zürich Water Supply, in German.

Gammeter, S. and U. Zimmermann, 2001. Changes in phytoplankton productivity and composition during reoligotrophication in two Swiss lakes. Verh. Internat. Verein. Limnol. 27., SIL, Dublin, in press.

Gilboa-Garber, N., 1971. Direct spectrophotometric determination of inorganic sulfide in biological materials and in other complex mixtures. Anal. Biochem. 43: 129-133.

Golterman, H.L., R.S. Clymo and M.A.M. Ohnstad, 1978. Methods for physical and chemical analysis of freshwaters. IBP Handbook No. 8, Blackwell Sci. Publ., Oxford, U. K., 213 pp.

Hanselmann, K. and R. Hutter, 1998. Geomicrobiological coupling of sulfur and iron cycling in anoxic sediments of a meromictic lakes: sulfate reduction and sulfide sources and sinks in Lake Cadagno. Documenta № 63 dell' Istituto Italiano di Idrobiologia, Suppl. delle Memorie dell'Istituto Italiano di Idrobiologia, ISSN 0393-8395, p 85-98.

Köhler, J., M. Schmitt, H. Krumbeck, M. Kapfer, E. Litchman and P.J. Neale, 2001. Effects of UV on carbon assimilation of phytoplankton in a mixed water column. Aquat. Sci. 63: 294-309.

Kurmayer, R. and F. Jüttner, 1999. Strategies for the co-existence of zooplankton with the toxic cyanobacterium Planktothrix rubescens in Lake Zürich. J. Plankton Res. 21: 659-683.

Kutschke, I., 1966. Die thermischen Verhältnisse im Zürichsee zwischen 1937 und 1963 und ihre Beeinflussung durch meteorologische Faktoren. Vierteljahrsschr. Naturforsch. Ges. Zürich 111: 47-124.

Lachavanne, J.-B., J.-M. Jaquet, R. Juge and J. Perfetta, 1985. Zustand, Erhaltung und Schutz der Ufer des Vierwaldstättersees. Herausgeber: Bundesamt für Forstwesen und Landschaftschutz, Bundesamt für Umweltschutz, Aufsichtskommission Vierwaldstättersee und Universität Genf.

Lehmann C. and R. Bachofen, 1999. Images of concentrations of dissolved sulphide in the sediment of a lake and implications for internal sulphur cycling. Sedimentology 46: 537-544.

Meyns, S., R. Illi and B. Ribi, 1994. Comparison of chlorophyll $a$ analysis by HPLC and spectrophotometry: Where do the differences come from? Arch. Hydrobiol. 132: 129-139.

Micheletti, S., F. Schanz, and A.E. Walsby, 1998. The daily integral of photosynthesis by Planktothrix rubescens during summer stratification and autumnal mixing in Lake Zürich. New Phytol. 139: 233-246. 
Murray, A.P., C.F. Gibbs, A.R. Longmore and D.J. Flett, 1986. Determination of chlorophyll in marine waters: intercomparison of a rapid HPLC method with full HPLC, spectrophotometric and fluorometric methods. Mar. Chem. 19: 211-227.

Neale, P.J., E. Litchman, C. Sobrino, C. Callieri, G. Morabito, V. Montecino, Y. Huot, P. Bossard, C. Lehmann and D. Steiner, 2001a. Quantifying the response of phytoplankton photosynthesis to ultraviolet radiation: Biological weighting functions versus in situ measurements in two Swiss lakes. Aquat. Sci. 63: 265-285.

Neale, P.J., P. Bossard and Y. Huot, 2001 b. Incident and in situ irradiance in Lakes Cadagno and Lucerne: A comparison of methods and models. Aquat. Sci. 63: 250-264.

Oern, C.G., 1980. Die Sauerstoffverhältnisse im Zürichsee (Untersee) von 1937 bis 1975 und ihre Beeinflussung duch meteorologische Faktoren. Vierteljahrsschr. Naturforsch. Ges. Zürich 125: 259-364.

Pasini P., 1999. UVB-Strahlung und Photosynthese-Hemmung im Zürichsee, sowie in den Hochgebirgsseen Lago Cadagno und Lago Scuro. Diplomarbeit, Universität Zürich. 89 pp.

Pasini P., and F. Schanz, 1998. Influence of UV-radiation on the primary production of two high mountain lakes in the Piora Region. Documenta № 63 dell' Istituto Italiano di Idrobiologia, Suppl. delle Memorie dell'Istituto Italiano di Idrobiologia, ISSN 0393-8395, p 65-70.

Peduzzi R., R. Bachofen and M. Tonolla (eds), 1998. Lake Cadagno: a meromictic alpine lake. Documenta No 63 dell'Istituto Italiano di Idrobiologia, 28922 Verbania Pallanza, Italy. Suppl. delle Memorie dell'Istituto Italiano di Idrobiologia, ISSN 0393-8395, pp 152.

Platt T., C.L. Gallegos and W.G. Harrison, 1980. Photoinhibition of photosynthesis in natural assemblages of marine phytoplankton. J. Mar. Res. 38: 687-701.

Rodhe, W., 1958. The primary production in lakes: some results and restrictions of the ${ }^{14} \mathrm{C}-\mathrm{meth}-$ ods. Rapp Proc.-verb. J. Cons. Perm. Int. Expl. Mer. 144: 122-128.

Schanz, F., 1994. Oligotrophication of Lake Zürich as reflected in Secchi depth measurements. Annales de Limnologie 30: 57-65.

Schanz, F., 1986. Depth distribution of phytoplankton and associated spectral changes in downward irradiance in Lake Zürich, 1980/81. Hydrobiologia 134: 183-192.

Schanz, F., 1985. Vertical light attenuation and phytoplankton development in Lake Zurich. Limnol. Oceanogr. 30: 299-310.

Schanz, F., 1982. A fluorometric method of determining chlorophll $a$ and pheophytin $a$ concentrations. Arch. Hydrobiol. Beih. 16: 91-100.

Schanz F. and S. Stalder, 1998. Phytoplankton summer dynamics and sedimentation in the thermally stratified Lake Cadagno. Documenta № 63 dell' Istituto Italiano di Idrobiologia, Suppl. delle Memorie dell'Istituto Italiano di Idrobiologia, ISSN 0393-8395, p 71-76.

Schanz, F., C. Fischer-Romero and R. Bachofen, 1998. Photosynthetic production and photoadaptation of phototrophic sulfur bacteria in Lake Cadagno (Switzerland). Limnol. Oceanogr. 43: $1262-1269$.

Schanz, F. and C. Friedl, 1993. Environmental effects on light utilization by phytoplankton in a meromictic alpine lake. Verh. Int. Verein. Limnol. 25: 621-624.

Schanz, F. and E.A. Thomas, 1981. Reversal of eutrophication in Lake Zürich. W.H.O. Wat. Qual. Bull. 6: 108-122, 156.

Schmid, M. and H. Ambühl, 1965. Die Bestimmung geringster Mengen von Gesamtphosphor im Wasser von Binnenseen. Schweiz. Z. Hydrol., 27: 184-192.

Standard Methods for the Examination of Water and Wastewater, 1971. New York, Amer. Publ. Health Ass.

Thomas, E.A., 1965. Verlauf der Eutrophierung des Zürichsees. Mitt. Österr. Sanitätsverwaltung 66: 3-11.

Tonolla, M., A. Demarta and R. Peduzzi. La chimica del Lago di Cadagno, 1998. In: Peduzzi et al. (eds.). Documenta $\mathrm{N}^{\circ} 63$ dell' Istituto Italiano di Idrobiologia, Suppl. delle Memorie dell'Istituto Italiano di Idrobiologia, ISSN 0393-8395, p 11-17.

Tonolla, M., A. Demarta and R. Peduzzi (1999). Phylogenetic biodiversity and in situ detection (whole cell hydbridisation) of the microbial flora from Lake Cadagno. Boll. Soc. Tic. 87: 57-66.

Uehlinger, U., and J. Bloesch, 1989. Primary production of different phytoplankton size classes in an oligo-mesotrophic Swiss lake. Arch. Hydrobiol. 116: 1-22.

Utermöhl, H., 1958. Zur Vervollkommnung der quantitativen Phytoplankton-Methodik. Mitt. Int. Verein. Limnol. 9: 1-38. 
Vogler, P., 1965. Beiträge zur Phosphatanalytik in der Limnologie. Fortschr. Wasserchemie u. Grenzgebiete. 2: 109-119.

Walsby, A.E., A. Avery and F. Schanz, 1998. The critical pressure of gas vesicles in Planktothrix rubescens in relation to the depth of winter mixing in lake Zürich, Switzerland. J. Plankton Res. 20: 1357-1375.

Züllig, H., 1982. Untersuchungen über die Stratigraphie von Carotinoiden im geschichteten Sediment von 10 Schweizer Seen zur Erkundung früherer Phytoplankton-Entfaltungen. Schweiz. Z. Hydrol. 44: 1-98.

Received 27 February 2001;

revised manuscript accepted 22 June 2001.

\section{(20) To access this journal online: \\ (20) http://www.birkhauser.ch}

